\title{
Reforms, Macroeconomic Policy and Economic Performance in Germany $^{\dagger}$
}

\author{
Wendy Carlin \\ University College London and CEPR \\ and \\ David Soskice
}

Duke University, Wissenschaftszentrum Berlin and European Institute, LSE

Revised July 2007

\begin{abstract}
The conventional diagnosis of Germany's poor economic performance focuses on supplyside weaknesses and the need for more vigorous reforms to make low-skill labour markets more flexible. We question this on both theoretical and empirical grounds. In an extended version of a New Keynesian model shifts in aggregate demand can move the economy along a range of constant-inflation medium-run unemployment equilibria. The evolution of the real exchange rate and the external balance help to identify whether aggregate supply or aggregate demand shifts have been dominant in accounting for changes in unemployment. We provide some prima facie evidence for Germany and the UK that aggregate demand factors have played an important role in sustaining growth in the UK and weakening it in Germany over the medium run. We show that Germany has a relatively strong record in implementing OECD recommended reforms but the expected employment effects in low-skill service sectors appear disappointing and poverty has increased. By contrast, it is in high productivity sectors including services that the German economy has performed well, especially in exports. Here labour markets are not flexible in the conventional sense: codetermination, vocational training, and coordinated wage bargaining are important. We pursue the implications of these claims for the design and political economy of reforms in Germany.
\end{abstract}

\footnotetext{
${ }^{\dagger}$ We are grateful for the excellent research assistance provided by James Cloyne and Etienne Hans and for useful discussions about these questions with Andrea Boltho, Andrew Glyn, Bob Hancke and Matthew Harding. Andrea Bassanini, Romain Duval and Luca Nunziata have kindly provided data. Useful comments were received at the CEPR-ECB-Bank of Italy Conference on 'Globalisation, EMU and the Reshaping of European Economies' at the EUI Florence in June 2007. An earlier version of this paper has been published in German (Carlin and Soskice, 2007).
} 


\section{Introduction}

This paper maps out a set of broad hypotheses for understanding what are prima facie contradictory trends in the German economy over the last decade or so. By international standards, West Germany was a low unemployment country although there was an upward trend over the 1970s and 1980s. During the 1990s and 2000s, Germany implemented prescribed reforms (e.g. in line with OECD recommendations) to make its labour (and product) markets more flexible, and according to OECD and many academic studies, would have expected to experience a fall in unemployment: yet it continued to rise. Moreover we might have expected that low skill service sector markets would be the beneficiaries of reform. While a full analysis of the data is needed before definitive conclusions can be drawn, it does not seem as though there has been a substantial expansion of employment in low skill service sector industries. Unemployment is still low-skill intensive and there seems to have been an increase in wage inequality and a rise in poverty. ${ }^{1}$ Worryingly, secondary education in Germany is no longer (if the PISA studies are accurate) as excellent as comparative studies in the 1980s showed it to have been; and there are also suggestions that the vocational training system no longer provides apprenticeships for many low attaining children.

These problems do not, by contrast, appear to have affected the high value-added export sectors of the German economy. Unlike all of the other large OECD countries, Germany's export performance improved over the decade to 2006 (7\% as compared with falls of $20 \%$ (US), about $10 \%$ (UK and Japan), $16 \%$ (France) and $60 \%$ (Italy)). ${ }^{2}$ This success is confirmed by studies of comparative innovation performance, where the 2005 European Innovation Scoreboard (European Commission) put Germany in the leading group of European countries with Denmark, Sweden, Finland and Switzerland, and ahead of both the UK and Ireland. ${ }^{3}$

What is perhaps surprising is that it is in these export sectors that the German model of employee representation and protection, the apprenticeship system and collective bargaining continue to operate most strongly. This German model has been reformed significantly since 1990, largely by direct negotiation between business associations and unions at sectoral level and/or management and works council at company level - reforms in which the government has played little part. Perhaps the most notable change has been the extent to which works council chairs (elected by employees) have been brought into de facto co-management of large companies. But these reforms have not been in the direction of flexible labour markets as usually understood in the contemporary policy debate.

Our first hypothesis for explaining these contradictory patterns is that a major underlying cause of the high unemployment is an aggregate demand insufficiency. But here there is a problem. While we subscribe to what is often now referred to as New Keynesian macroeconomics, its standard version offers little help in explaining why demand shocks are persistent. We shall argue that there are a number of reasons why the standard New Keynesian model does not explain well what has happened in Germany in the last fifteen

\footnotetext{
${ }^{1}$ The poverty rate in Germany in 2001 was $8.9 \%$ and it increased by 0.6 percentage points from 1994 to 2001 with the increase concentrated in the age group below 40 years (Förster and Mira d'Ercole, 2005, Annex Table A7).

${ }^{2}$ This is the ten year cumulated OECD measure of the change in export performance (export volume divided by total exports of goods and services). OECD Economic Outlook 80, Annex Table 44. A similar picture emerges from alternative measures - e.g. the change in the export market share of exports or of exports less imports.

${ }^{3}$ See also Cotis (2006) for similar results using OECD Main Science and Technology Indicators Database, R\&D database and Patent database.
} 
years or so. Germany suffered a series of adverse shocks including monetary retrenchment in 1993-4, fulfilment of the Maastricht conditions in 1994-9 and the oil price increase and external deflationary pressures of 2004-5 and we identify a number of mechanisms that prevented stabilization from occurring in the way the New Keynesian model assumes it does. These 'non-dampeners' allowed the shocks to persist. Moreover, these mechanisms do not apply to the UK or the US.

Our first hypothesis is therefore that aggregate demand insufficiency has been the underlying cause of persistent unemployment. Our second hypothesis relates to the implications of this for labour market flexibility. As we have noted, the successful areas of the German economy are successful because they do not have flexible labour markets in the conventional sense. We hypothesise that the internal political pressure to make a range of service sector labour markets more flexible, in part by welfare state cuts, came from the rise in unemployment (a consequence of insufficient aggregate demand) and the need to cut government expenditure because of the exigencies of the Maastricht Treaty and the Stability and Growth Pact. Almost inevitably, the rise in unemployment fell on less skilled workers.

Flexible labour markets do not magically create employment by themselves: they require an adequate level of aggregate demand, which in the canonical New Keynesian model, is ensured by active monetary policy. Legislation that creates flexible labour markets in the context of inadequate demand leads to limited increases in employment and falling wages (as suggested, for example, by research on minimum wages in the US). Thus the danger of introducing flexible labour market legislation in Germany in the context of depressed aggregate demand is that income distribution becomes more inegalitarian and poverty increases. These effects are then amplified by welfare state cutbacks, which fall primarily on those with low skills and low incomes so that redistribution becomes more limited. The worsening income distribution and the rise in poverty may also lead to a worsening of educational outcomes and the apprenticeship system is put under pressure at its lower end as a result of

(a) the worsening of educational outcomes, imposing de facto higher training costs on employers;

(b) labour market flexibility, which means that employers can hire semi-skilled labour more cheaply and hence not benefit from using apprentices to do some of the semi-skilled work;

(c) lack of aggregate demand, which implies a reduction in the projected size of skilled workforces in training companies.

Our third hypothesis is that the failure to make it easy for women to re-enter the labour market after a period of bringing up children at the same wage and conditions as before reinforces and is reinforced by the first two hypotheses. A system in which women can enter and re-enter employment easily acts as a potentially strong additional insurance mechanism in an economy in which male workers with specific skills are risk-averse. It would act to prevent poverty especially for single mothers and it would give an incentive to parents to increase the reproduction rate and hence to reduce the long-term pressure on the welfare state.

In Section 1, we sketch the salient features of German labour market institutions relevant to our argument. In Section 2, we set out the economic case for reinstating a leading role for aggregate demand alongside supply-side factors in the analysis of German economic performance. In Section 3, we present a number of pieces of evidence that we hope will 
stimulate others to investigate our hypotheses in more depth. We concentrate on a comparison between the UK, where liberalizing economic reforms are widely believed to lie behind economic success and Germany, where failure to reform is often blamed for its dismal economic performance. The role of positive aggregate demand shifts in the UK and negative ones in Germany is documented as candidates for explaining changes in unemployment. We investigate the extent to which Germany has implemented labour market reforms and the evidence that such reforms should have reduced unemployment. And we ask whether such reforms could themselves have depressed aggregate demand. Section 4 concludes.

\section{Labour Market Flexibility and German Institutions}

A major difference between the German political economy on the one hand and those of the UK and the US on the other relates to the organisation of labour markets: in Germany a small number of powerful unions and employer associations, mainly located in the export sector, play a leading role in wage setting. This contrasts with decentralized labour markets in the Anglo-Saxon economies. The second difference is in the structure of political systems: Germany has what Lijphart (1984) called a consensus system, with proportional representation and consequent coalition governments; while the UK and US are majoritarian systems with first-past-the-post elections and single party government (for all their other differences). There are two other important and well-known differences: Germany has a stronger welfare state (with a relatively high replacement rate) than the UK or the US (continental rather than liberal in Esping-Andersen's terminology (1990)). And Germany has as well a vocational training system in which companies play a leading role, and in which young workers acquire relatively deep skills specific to a sector and to a considerable extent to a firm. By contrast, the UK and the US place far more emphasis on general education and training.

These differences in industrial relations, political systems, welfare states and education and training, are not random, but have co-evolved in ways which imply powerful complementarities. In the German (and northern European systems more generally), workers with firm- and sector-specific skills are in a powerful position within their firm thus paradoxically strong unions that keep wage bargaining outside the company are necessary to guarantee the long-term cooperative behaviour of the skilled insiders. Strong welfare states provide insurance for workers with specific skills in case they do lose their job; and behind the welfare state, the consensus political system underwrites their interests. Indeed, if the society wishes to encourage investments in specific skills and if those with specific skills need the insurance of a strong welfare state, then the political system has to guarantee that institutional change requires wide agreement (Iversen 2005). The complementarities operate in quite different ways in the UK and the US. Hall and Soskice (2001) describe the two types of political economies as different varieties of capitalism - liberal market economies (LMEs) in the case of the Anglo-Saxon countries and coordinated market economies (CMEs) for the northern European. While its institutions are very different, Japan is a type of CME with recognisably functionally equivalent systems. Its problems in the past decade can be analysed in similar ways to those in Germany (Vogel 2006).

We suggest that the very different type of labour market and skill organisation in Germany in comparison to the UK and the US leads to problems for consumption behaviour in the former but not the latter. Employees with specific skills can be expected to react with particular concern to a slowdown in growth, a rise in unemployment and the fear of welfare state reforms to unemployment benefits and to pensions. For workers with specific 
skills it will generally be harder to find appropriate re-employment if they lose their jobs. Moreover, there is a negative externality in a labour market dominated by specific skills. If most of the work force has long-term employment, the number of vacancies within a given category of employment is likely to be limited; and companies may anyway seek to fill vacancies via apprenticeships. Thus mid-career labour markets for many categories may be quite limited or "illiquid". The most obvious comparative example of this is with lifetime employment in Japan: in the relevant categories, mid-career labour markets do not exist, short of accepting a position in a subsidiary company.

In Germany as in Japan, illiquidity of mid-career labour markets applies more to the relatively more highly skilled - since firms have already invested more in them and, since it pays companies to invest more in them, they have longer tenure. Less skilled workers, but still with apprenticeship certificates, face more open occupational labour markets which are what portable qualifications should equip them to do. Given serious concerns about unemployment and with governmental pressure for welfare state reform in unemployment benefits and pensions (in Japan equivalently ending "lifetime" employment), those with specific skills who remain employed - in fact the great majority - respond by building up savings. The rise in savings results not from an interest rate incentive to substitute future for present consumption but from increased precautionary savings, and in response to actual recent cuts in state pension entitlements, increased lifecycle savings.

Iversen's (2005) analysis of the guarantor-insurance role of the welfare state for those with deep specific skills in a coordinated market economy explains why this substantial proportion of the workforce should feel insecure as its welfare state benefits start to be questioned. Many employees factor in the possibility of involuntary early retirement or part-time work from their mid-50s should economic conditions become difficult - both schemes which depend on welfare state provision. By contrast to liberal market economies such as the UK or US where a workforce with more general skills could imagine at a similar age responding to economic difficulty by finding alternative employment, labour markets for older workers do not exist on any substantial scale in Germany.

These fears are exacerbated by the consensus nature of political institutions in CMEs. As discussed above, this reflects an economic environment in which institutional change requires wide agreement if the environment is to continue to encourage investments in specific assets. To summarise, our claim is that the specificity of skills in Germany, aggravated by uncertainty about the future of the protective welfare state, amplifies any adverse aggregate demand shock by further dampening household consumption growth. This effect is likely to be reinforced by the fact that the German labour market and welfare state are characterized by provisions that encourage single earner households. The difficulty for women with children to enter and reenter the labour market depresses women's participation and weakens an important insurance mechanism for families with risk-averse male workers with specific skills.

Over the past decade and a half the German economy has become increasingly characterized by two separate labour systems: one in the core export-oriented sector of the economy and the other 'outsider' labour system, which has been the focus of government labour market reforms. The reform of the core labour system has been extensive and successful. Moreover, the reform has been carried out by private sector agents (unions, employers' associations, firms, works councils) without a significant role for the government. The restructuring has entailed increased consensus-based decision making in firms with works council chairs playing a greater role in co-management (e.g. Höpner, 
2003). The median (i.e. skilled) employee interest has become increasingly aligned with the firm's. Whilst industry unions still play a major role in coordinated wage bargaining and vocational training, both have become more oriented to company needs (Thelen, 2007). Industry unions are more dominated than in the past by major works council chairs.

Key changes since the early 1990s include the collapse of coordinated bargaining in East Germany where the attempt to reproduce the core German model largely failed. In West Germany smaller firms have tended to leave the formal wage-setting system but small firm associations now shadow coordinated wage bargaining since the reasons for not wanting internal firm-level wage-setting prevail. There has been a shift in a range of tariffrelated bargaining areas from union to firm-works council level (e.g. part-time working for older workers) negotiated with the unions and with input from works councils. We shall return below to the successful performance of the export-oriented part of the German economy based at least in part on the ability of the labour system to adapt flexibly to the challenges presented by globalization.

The long period of high unemployment in Germany, which we argue in the next section is largely an aggregate demand phenomenon, prompted welfare state and labour market reforms of the traditional kind (beginning in the mid 1990s and culminating in the extensive Hartz IV reforms implemented in 2004). The effect has been to leave particular groups such as the low skilled, immigrants and East Germans outside the generous German welfare state, whilst employees in the core labour system are still relatively protected. Inequality at the bottom of the wage distribution has increased as collective bargaining ceased to cover them (Dustmann, Ludsteck and Schönberg, 2007). At the same time it appears that the children of those in the outsider labour system are likely to be increasingly excluded from the vocational training system, an outcome reinforced by the worsening performance of children in the lowest secondary school track (e.g. PISA evidence). This may reflect the diminished motivational role for children in the lower tail of the ability distribution that was previously played by the existence of a more or less continuous ladder of apprenticeships by quality, which led from lower tier apprenticeships to semi-skilled jobs (Soskice, 1994).

We can sum up the argument in this section by noting that government reforms (broadly in line with the advice of the OECD and the consensus amongst economic observers) have reinforced the outsider labour system with some unintended consequences. These include increased segregation between the two labour systems, increased poverty and inequality and reduced school performance reflecting perceived lower chances of entering the core labour market. By contrast, the core labour system itself has been characterized by continuity combined with effective restructuring by the private agents themselves. Incremental organizational innovation has been undertaken in the face of external pressures from global product and financial markets that has been consistent with the essential characteristics of the 'German model'.

\section{Reinstating a Role for Aggregate Demand in Analyzing German Economic Performance}

This section is designed to show the potential importance of aggregate demand in explaining the persistent unemployment in the German economy. In addition we aim to explain why there are major institutional barriers, themselves reflecting underlying power structures, which make the weak demand problem so difficult to solve. In addition, as argued in Section 1 given the specificity of skills in the workforce and the consequent fear 
of unemployment, welfare state reform may have lead to a build up of precautionary savings and hence amplification of the demand slowdown. While we hope the section may clarify how adverse demand shocks have at least in part lead to unemployment persistence (for non-hysteresis reasons), we also argue that institutional infeasibility rather than technical incompetence has ruled out simple demand-management solutions.

The first sub-section explains how in an open economy a New Keynesian macro model can imply multiple unemployment equilibria, in which the equilibrium is chosen by the level of aggregate demand. ${ }^{4}$ Hence adverse demand shocks may lead to higher equilibrium unemployment. This is followed by an examination of potentially counteracting policy responses - monetary, fiscal and wage restraint policies. We show why each in turn is likely to be inadequate or even counterproductive.

\section{Multiple unemployment equilibria and aggregate demand in open economies}

Much of the work applying New Keynesian economics to the issue of aggregate unemployment has focussed on the closed economy. It is useful to start this section by setting out, using New Keynesian assumptions of imperfect product and labour markets, how the equilibrium rate of unemployment is derived in the closed economy and why it is unique. This will enable us to contrast the analysis for the open economy in which, using analogous assumptions, there may be multiple unemployment equilibria.

In the New Keynesian model, equilibrium unemployment depends on the implications for real wages which come from wage-setting on the one hand and price setting on the other. Both wage-setting and price-setting are nominal operations, but the goal in the first is some level of the real wage and in the second of real profits. Wage-setting can be carried out by employers alone ('efficiency wages') or as a result of bargaining. Here we focus on wage bargaining: unions bargain for an expected real wage. The lower the level of aggregate unemployment, the higher the bargained expected real wage, $w^{W S}$. But real wages are also set implicitly as a result of price-setting. Taking the simplest case of unit labour productivity, nominal unit cost is simply the money wage $W$. And suppose product markets enable businesses to set a mark-up of $1+\mu$ on unit costs (where the mark-up covers fixed costs as well as a monopoly element), so that the price level $P=(1+\mu) W$, which implies a (price-setting) real wage of. $w^{P S}=W / P=1 /(1+\mu)$.

Equilibrium is defined as a constant rate of inflation. In equilibrium, the bargained real wage $w^{W S}$ must equal the price setting real wage $w^{P S}$. This is because if, say $w^{W S}>w$ by $1 \%$, wage bargainers will believe they can raise the real wage by $1 \%$; so if pre-existing inflation is $2 \%$, this implies that unions will individually set nominal wage inflation at $3 \%$ , in the belief that the real wage will increase by $1 \%$. However this implies that businesses with raise prices by $3 \%$ to restore their mark-up. And if this process continues nominal wage inflation and price inflation will subsequently rise to 4\%; and so on. So for equilibrium, the bargainable real wage $w^{W S}$ needs to be equal to the price-setting real wage. If the unemployment rate is too low, $w^{W S}>w$; if too high $w^{W S}<w$, so the equilibrium unemployment rate brings $w^{W S}$ into line with $w^{P S}$.

Some useful consequences are as follows. Union bargaining power tends to be higher the lower the elasticity of demand in the (aggregated) product markets which correspond to union bargaining coverage, since an increase in the bargained real wage implies a smaller fall in employment; hence equilibrium unemployment needs to be higher to bring down $w^{W S}$ into line with $w^{P S}$. Since the more aggregated the product market is (i.e. the more sub-

\footnotetext{
${ }^{4}$ For a more extensive presentation of some of this material, see Carlin and Soskice (2006).
} 
sectors it covers) the more inelastic will be product demand, and at the same time the smaller will be the overall number of unions: so, ceteris paribus, the smaller the number of unions the higher the equilibrium unemployment rate. (There is a double whammy here, for the more inelastic product demand the larger will be the pricing mark-up $\mu$, and hence the lower the price-setting real wage - also pushing up the equilibrium rate of unemployment.) But cetera are not necessarily pares: wage restraint, the foregoing of bargaining power, allows the equilibrium unemployment rate to fall, and small numbers of unions may be better able than larger numbers to organise wage restraint.

Unfortunately for comparative policy analysis, much less work has been done in open economies. There is however a persuasive argument that there may be many unemployment equilibria in open economies. ${ }^{5}$ In the open economy equilibrium unemployment is determined as in the closed by the requirement that the bargained real wage, $w^{W S}$, is equal to the real wage implied by price-setting, $w^{P S}$. The bargained real wage is determined as before, and we will keep with the simple case in which it declines as unemployment rises. But $w^{P S}$ is different. This is because the price level is now a weighted average of domestic costs of production $(W)$ and world prices $\left(P^{*}\right)$. World prices are important since they directly affect import costs and indirectly impose limits on markups as a consequence of potential competition. If $P^{*}$ is high relative to $P$, that reduces the real wage for two reasons - it implies a high real cost of imports and it enables domestic companies to set a high profit mark-up. The ratio $P / P^{*}$ is the real exchange rate ${ }^{6}$ a high real exchange rate means a high price-setting real wage (low cost of imports and low profit mark-up), and vice versa. Thus a high real exchange rate allows a high bargained real wage and hence a low equilibrium level of unemployment, and vice versa.

Figure 1.

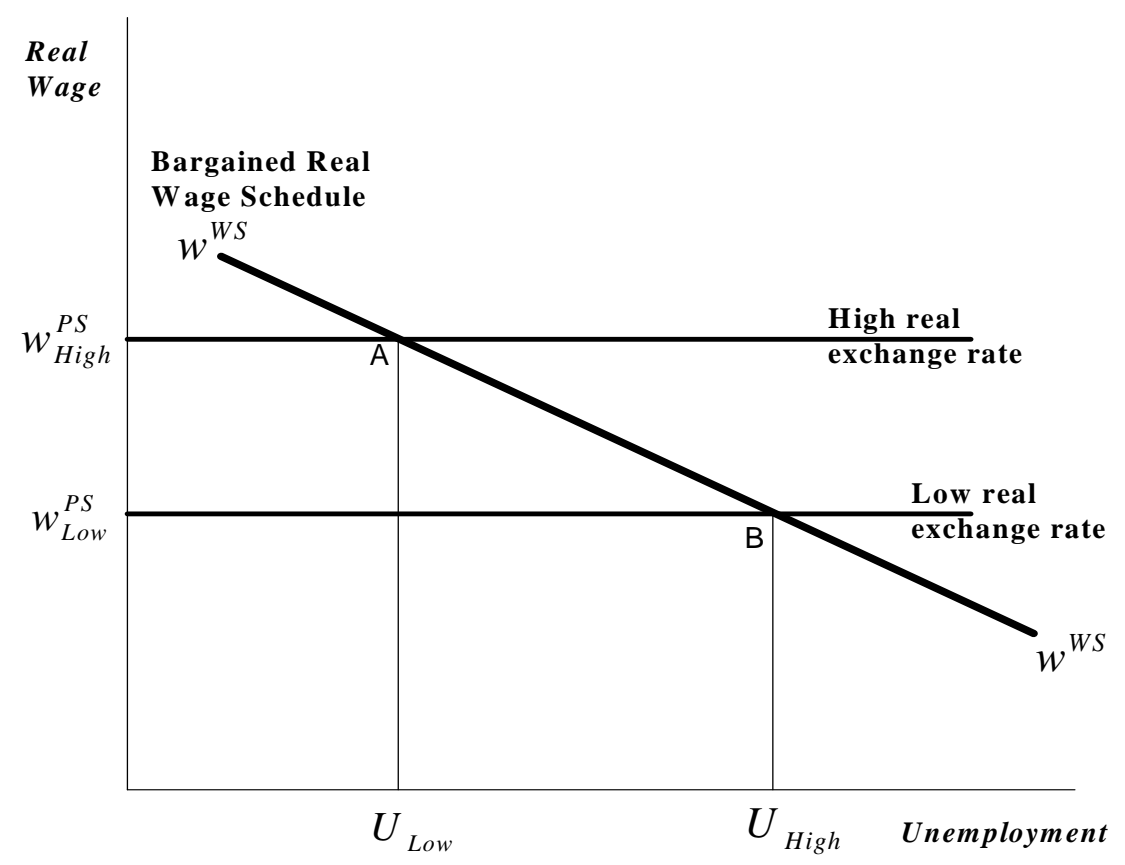

\footnotetext{
${ }^{5}$ For early treatments, see Rowthorn (1977), Carlin and Soskice (1990), Layard, Nickell and Jackman (1990).

${ }^{6}$ This assumes that the nominal exchange rate is fixed at 1 ; since we are analyzing Germany as a member of EMU we will maintain this assumption - though note this does not take account of variations in the value of the Euro itself.
} 
In Fig. 1, the real wage is on the vertical axis, with unemployment on the horizontal. The downward sloping relationship shows how the bargained real wage, $w^{W S}$, declines as aggregate unemployment increases. The real wage implied by price-setting is high when the real exchange rate is high, $w_{H i g h}^{P S}$, since the real cost of imports is then low and the profit mark-up is subdued because of the competitive effects of low world prices. So when the real exchange rate is high, the high price-setting real wage means that the bargained or wage-setting real wage will also be high in equilibrium; and that allows equilibrium unemployment to be low, $U_{\text {Low }}$, as shown by the intersection at $\mathrm{A}$.

By contrast, a low real exchange rate implies a low price-setting real wage, hence a low bargained real wage and a high unemployment rate in equilibrium, indicated by the intersection at $\mathrm{B}$.

How is the equilibrium rate of unemployment chosen? A central part of the analysis is that the equilibrium is determined by aggregate demand. Figure 2 shows how, in the face of a negative aggregate demand shock and in the absence of any counteracting policies, a new higher unemployment stable inflation equilibrium is established. Assume the economy is initially in equilibrium at $A$ with low equilibrium unemployment and a high real wage, $w^{W S}=w_{H i g h}^{P S}$, with high aggregate demand implying low actual equal to low equilibrium unemployment. There is then an adverse demand shock, shown in Fig. 2 by the rightward shift of the vertical aggregate demand dashed line. This pushes up unemployment and pushes down the bargained real, so that the actual real wage $\left(w_{H i g h}^{P S}\right)$ is now above the bargained real wage (say, by $2 \%$ ). The consequence is that employers bargaining with unions will be able to push down the real wage.

Figure 2.

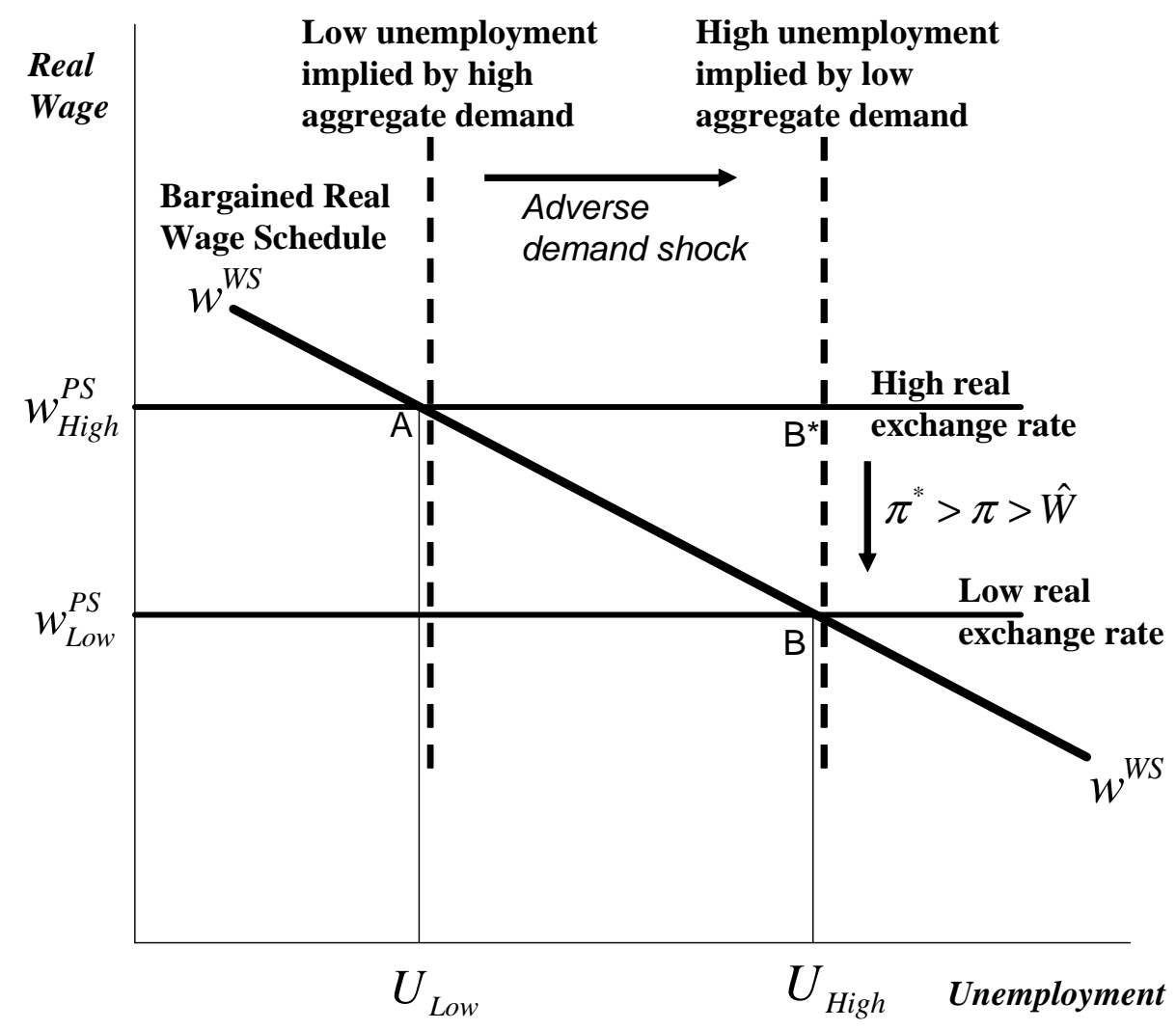


Suppose initially that world inflation, domestic inflation and nominal wage inflation are all 3\%, implying a constant real exchange rate (since domestic inflation is equal to world inflation) and a constant real wage (since nominal wage inflation is equal to domestic inflation). Then if wage bargainers in year 1 believe domestic inflation will continue at $3 \%$, money wage inflation will fall to $1 \%$ to engineer an expected real wage cut of $2 \%$. What do price setters do in consequence of these $1 \%$ money wage increases? Domestic inflation is a weighted average of money wage inflation and world price inflation, so the fall in money wage inflation will reduce domestic inflation relative to world inflation and this will reduce the real exchange rate. Thus, if for example, domestic inflation $(\pi)$ is composed half of money wage inflation $(\hat{W})$ and half of world price inflation $\left(\pi^{*}\right)$, domestic price inflation will fall to $2 \%(\pi=.5 \hat{W}+.5 \pi *=.5 \times 1 \%+.5 \times 3 \%=2 \%)$. Hence the real exchange rate will fall by $1 \%$, since domestic inflation of $2 \%$ is $1 \%$ below world price inflation of 3\%; and the real wage will have fallen by $1 \%$ as well. So the economy will have moved half way down the vertical line between $B^{*}$ and $B$.

The next year, a similar process will be repeated in wage bargaining (since the real wage is now $1 \%$ above the bargained real wage), and price-setting, and it will continue until the economy is eventually at B. (In fact with rational expectations, this process could take place immediately, with $\hat{W}=-1 \%$ and $\pi=1 \%$ for just one period while $\pi^{*}$ remains at $3 \%$; with all three rates reverting back to $3 \%$ the next period; so the real wage and the real exchange rate both fall by $2 \%$; the economy then moves at once to its new equilibrium at B.)

\section{Monetary policy and the ECB}

In the standard closed economy model with a well-behaved central bank, New Keynesian inflation-targeting monetary policy would respond to an adverse demand shock and the consequent fall in inflation below target by lowering interest rates and returning the economy to equilibrium within a reasonable period of time. ${ }^{7}$ It is useful to see why monetary policy does not work effectively in the case of a persistent adverse demand ('IS') shock in the open economy.

Since Germany constitutes about one-third of the EMU GDP, a rise in unemployment in the German economy may be big enough to trigger a relaxation of ECB monetary policy. However, as compared with having an independent monetary policy, one issue is the partially asymmetric ECB response function. Even so we might expect falling inflation in Germany to move the ECB eventually into action. The real problem is captured by the analysis in the previous paragraph: German inflation falls only temporarily because the German economy reaches a new higher unemployment equilibrium. Once the real wage has adjusted (downwards in this case) inflation returns to the common 'world' or EU rate and with inflation constant, the monetary policy reaction function even of an independent German central bank would not lead to a further cut in the interest rate.

This is then a situation in which stabilizing fiscal policy would be regarded as the appropriate move. It is to this that we now turn.

\section{Fiscal policy and institutional blockage}

There is something of a consensus today that monetary policy works more effectively than fiscal policy: central banks can change interest rates quickly; and they can avoid the inflationary bias associated with the desire of governments to choose below equilibrium

\footnotetext{
${ }^{7}$ For a simple exposition of how this works, see Carlin and Soskice (2005).
} 
unemployment rates. Fiscal policy takes longer to put into operation (because of planning lags, parliamentary time and so on); and it is subject to the time inconsistency problem of macroeconomic policy since politicians are taking the decisions (see, for example, Allsopp and Vines, 2006). But, equally, most New Keynesian economists accept that there are lacunae in monetary policy, and then governments need to resort to fiscal policy. ${ }^{8}$ The two most widely discussed situations in which monetary policy has shown itself actually or potentially ineffective are Japan in the last decade and asymmetric demand shocks in EMU (e.g. Allsopp and Vines, 2006, Krugman, 2006).

From a political economy point of view there are two institutional situations that have typically led to the creation of conservative frameworks for the operation of fiscal policy ruling out the possibility of the use of discretionary fiscal policy (except perhaps in extreme circumstances, as eventually in Japan).

The first situation is where there are a limited number of powerful wage bargainers who set the inflation rate and de facto the real exchange rate; we shall refer to this as the Small$\mathrm{N}$ case. These powerful unions, usually in industrial sectors but also in the public sector, themselves represent a spectrum ranging from core highly skilled members in no danger of losing their jobs even with sizeable real wage increases to more substitutable employees in more marginally profitable companies or industries. Assume these unions were acting independently (only partly true), and assume that the government was pursuing a discretionary fiscal policy to respond to increased unemployment, then each union is big enough to believe that an increase in unemployment as a result of its own actions will lead to some response by the government of the order of $1 / \mathrm{N}$. By abandoning discretionary fiscal policy and therefore removing this possibility, the government sharpens the incentives for wage moderation.

This analysis certainly applies to Germany. The coordination of wage bargaining that we observe in Germany is an ex-post phenomenon reflecting the understanding of the major unions that any one of them is in a position to gain serious real wage increases and in turn that this would put pressure on other unions to be more aggressive. Given the fear of sharp conservative responses to inflation this has led to concerns across the major unions with the outcome of coordinated restraint.

Note that the prospect of discretionary fiscal policy has no effect when labour markets are flexible, or if there are a great many independent bargaining units, since no wage-setter believes that the tiny increase in unemployment resulting from its own wage bargain will change government expenditure. So neither the UK nor the US with flexible labour markets should fear the effect of discretionary fiscal policy. Equally, countries with encompassing wage bargainers, or countries in which all the relevant wage bargainers sit around a table with the government and make a binding wage contract should be happy to conduct a flexible fiscal policy.

\footnotetext{
${ }^{8}$ Interestingly in New Keynesian dynamic stochastic general equilibrium models of the closed economy, it is difficult to reproduce the empirically documented positive response of consumption to an increase in government spending. Gali, Lopez-Salido and Valles (2007) show that a proportion of 'rule-of-thumb' liquidity constrained households, sticky prices producing a pro-cyclical squeeze on profit margins, imperfect competition in the labour market and a zero weight on output in the Taylor Rule are required. In the open economy, however, the endogenous change in the real exchange rate / terms of trade would appear to produce this result more readily by generating the required change in the real wage (although to our knowledge this has not been rigorously investigated either in the Gali et al. set-up or in an OLG framework). For a recent survey, see Coutinho (2005).
} 
Second, the structure of governments may affect the incentives for running a discretionary fiscal policy (Hallerberg and von Hagen, 2001). The basic argument is this: coalition government leads to a common pool problem if individual ministries with presumably different party preference functions can independently decide on expenditure while taxation is general. Expenditure will be too high with coalition government. Thus it will be in the interest of all the members of the coalition to work out a binding contract regarding how much each ministry (or party) should be allowed to spend. For the binding contract to work there needs to be a tough fiscal framework. This is likely to be at odds with a discretionary approach since there is a principal agent problem: whichever agent (say the Minister of Finance) is put in charge of the discretion will incite the concern of the principal (the other coalition members) that it is being used to the advantage of the Finance Minister's party. Hence coalition governments will be nervous about discretionary fiscal policy.

Coalition versus single party government is largely a product of the electoral system. Majoritarian systems nearly always produce single party government; proportional representation systems nearly always produce coalitions (or, what are de facto the same, minority governments with agreed support from other parties).

German governments have fought shy of discretionary fiscal policy because wage bargaining is carried out by a small number of powerful unions and because governments are nearly always coalitions. Historical experience of poor outcomes from the use of deficit financing in the Weimar period (McNeil 1988) and in the so-called Bonn locomotive episode of 1977-1982, when the US put strong pressure on the Schmidt government to engage in a fiscal expansion to stimulate growth and reduce global imbalances, is likely also to have played a role.

\section{Wage restraint in small and large economies.}

The above analysis is also a useful starting point for understanding the differential effects on unemployment of wage restraint in large and small open economies. Leading unions in northern European Small-N type systems typically represent export and industrial sectors. As noted in the last sub-section their membership covers a spectrum ranging from core highly skilled members in no danger of losing their jobs even with sizeable real wage increases to more substitutable employees in more marginally profitable companies or industries. Just focussing on the German case, unions have little to hope for from the government's fiscal policy in the event of an adverse demand shock (and even less from the ECB). Hence if they are concerned about the number of their members, this constrained policy-making framework is likely to push them to respond to adverse shocks with wage restraint. Thus with government and big business concerned about international competitiveness a tight fiscal policy is attractive. Indeed export sector union leaders themselves may not be too unhappy with constraints that enable them to resist demands to raise real wages and hence risk losing members. In this sub-section we follow this general line of argument and assume that unions respond to an adverse demand shock by wage restraint.

What we show is that, if unions in exposed sectors do respond in this way, the effects on a large economy like Germany may be as negative for the economy as a whole (but not for the export sectors) as they are positive in smaller open economies such as Sweden or the Netherlands. Here is the argument: 
Figure 3.

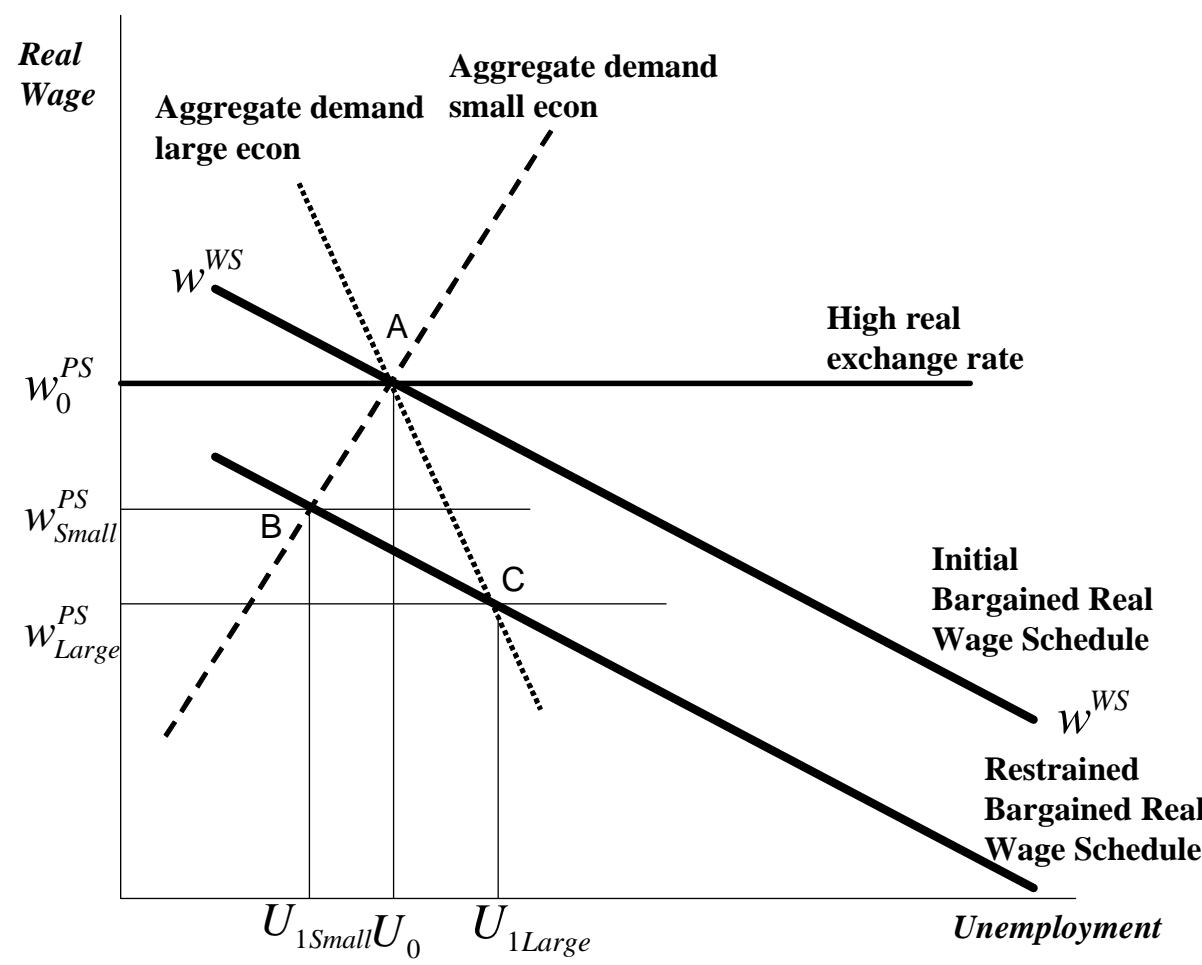

Both large and small economies are in equilibrium initially at $A$ in Fig. 3 with $w=w^{W S}=w_{0}^{P S}$ and $U=U_{0}$. The relevant bargained real wage schedule is labelled 'Initial'. We focus on a likely difference between the large and the small economy: the slope of the aggregate demand curves. The aggregate demand schedule in the small economy is shown by the long-dashed line and in the large economy, the short-dashed line. A policy of wage restraint in the open economy leads to a new equilibrium with lower real wages. A cut in the real wage has two opposite effects on aggregate demand: on the one hand, it improves international competitiveness by lowering the real exchange rate, increasing exports and reducing imports and hence raising aggregate demand and lowering unemployment. If this was the only effect, the aggregate demand curve in the diagram would be upward sloping. But a cut in the real wage also lowers consumption assuming that liquidity constraints prevent workers from smoothing consumption in response to the fall in the real wage. In a small and therefore more open economy we assume the first effect dominates so that a lower real wage leads to an economy wide improvement in unemployment (point B); and vice versa in a large economy (point $\mathrm{C}$ ); (in both cases employment in the export sectors should improve). ${ }^{9}$

\section{The UK and Germany: Comparative Performance, Reforms and Policies in the 1990s and 2000s}

In this section, we investigate the hypotheses set out in Section 2 by comparing the performance, aggregate demand behaviour and reform experience of the German and British economies. At first sight, the contrasting fortunes of the British and German economies over the past 15 years appear to conform to the mainstream view. The vigour

\footnotetext{
${ }^{9}$ Since the slope of the AD curve depends on the combined effect of real wages on net exports, consumption and investment, a full analysis would also include the impact of wage restraint on investment.
} 
with which supply side reforms have been undertaken in the UK since the 1980s is well known - as is the long period of robust growth, falling unemployment and low and stable inflation. Meanwhile Germany has been dogged by increasing unemployment and sluggish growth and deemed to have a sclerotic and unreformed supply side. ${ }^{10}$

Table 1. Economic performance: Germany and the UK

\begin{tabular}{|c|c|c|c|}
\hline & $\begin{array}{l}\text { Unemployment } \\
\text { rate (\%) }\end{array}$ & $\begin{array}{l}\text { Growth in real GDP } \\
(\% \text { p.a. })^{* *}\end{array}$ & Level of public sector debt to GDP, $(\%)^{* *}$ \\
\hline & G UK & G UK & UK \\
\hline 1980s & 5.8 & 2.6 & 48.7 \\
\hline 1990s & $7.0^{*}$ & 1.4 & 46.5 \\
\hline 00-05 & 8.5 & 1.1 & 43.5 \\
\hline & $\begin{array}{l}\text { Level of GDP p.c. } \\
\text { (US }=100), 2005\end{array}$ & $\begin{array}{l}\text { Level of GDP per } \\
\text { hour worked } \\
\text { (US }=100 \text { ) } 2005\end{array}$ & $\begin{array}{l}\text { Rank in OECD20 } \\
\text { absolute output gap; } \\
\text { CPI inflation (95-05) }\end{array}$ \\
\hline & 78.4 & $98.6 \quad 88.9$ & $8 ; 8 \quad 1 ; 6$ \\
\hline
\end{tabular}

Sources: Growth and levels of GDP pc. at purchasing power parity are from Groningen Growth and Development Centre and the Conference Board, Total Economy Database, May 2006, http://www.ggdc.net Other variables are from OECD Economic Outlook Database June 2006.

Notes: * includes East Germany from 1993; ** 1980-90; 1991-99; 2000-05; West Germany for the first period. Unemployment is the standardized measure of unemployment as reported by the OECD.

Table 1 provides comparative data for Germany and the UK, which shows the well known deterioration in unemployment performance in Germany throughout the period and its improvement in the UK. Similar contrasts are revealed in comparative growth performance and in levels of public sector indebtedness. The UK has also achieved remarkable macroeconomic stability in the past decade. It is ranked first amongst 20 OECD countries in having the lowest average absolute output gap and sixth for inflation stability. In terms of public sector stability as indicated by the lowest debt to GDP ratio, the UK ranked fifth in 2005. Across each of these dimensions, Germany performed worse. However, the relatively weak performance of British productivity growth is reflected in the fact that GDP per hour worked continues to be higher in Germany than in the UK, although longer hours of work and a higher employment rate give the UK $10 \%$ higher GDP per capita.

Table 2 reports some commonly cited indicators of the institutional environment. The first set refers to 'Economic Freedom' and the second to broader 'framework conditions' for economic performance. The two dimensions of the Fraser Institute Index of Economic Freedom that relate most closely to the concept of the free operation of market forces are 'Legal structure and property rights' and 'Regulation of labour, credit and business'. The World Economic Forum's Growth Competitiveness Index is a broad index of framework conditions: "Competitiveness is defined as that collection of factors, policies and institutions which determine the level of productivity of a country and that, therefore, determine the level of prosperity that can be attained by an economy." (2005, p.xiii). The WEF Business Competitiveness Index: “... specifically measures two areas that are critical to the microeconomic business environment in an economy: the sophistication of

\footnotetext{
${ }^{10}$ For a concise presentation of the evidence of the effects of reforms for the UK, which includes comparative data for Germany, see Card and Freeman (2004). For an extensive analysis of performance and reforms in Germany, see Siebert (2005); for a view along similar lines from 'the outside', see Heckman (2002).
} 
company operations and strategy, as well as the quality of the overarching national business environment in which they are operating." (p.xvi)

Table 2. Indicators of economic freedom and competitiveness, Germany and the UK

\begin{tabular}{|c|c|c|c|c|}
\hline \\
\hline & & & & Legal structure and property rights \\
\hline & 1980 & 1990 & 2003 & Rank in \\
\hline Germany & 7.7 & 8.3 & 8.9 & 7 \\
\hline \multirow[t]{3}{*}{ UK } & 7.0 & 7.7 & 9.2 & 5 \\
\hline & \multicolumn{4}{|c|}{ Regulation of credit, labour and business } \\
\hline & 1980 & 1990 & 2003 & $\begin{array}{l}\text { Rank in } \\
\text { OECD20,2003 }\end{array}$ \\
\hline Germany & 5.2 & 5.3 & 5.7 & 19 \\
\hline UK & 6.0 & 6.8 & 7.4 & 3 \\
\hline
\end{tabular}

\section{Competitiveness scores, 2005 (Rank in OECD20)}

\begin{tabular}{lllll} 
Growth competitiveness index & \multicolumn{2}{l}{$\begin{array}{l}\text { Sub-components: } \\
\text { Technology }\end{array}$} & $\begin{array}{l}\text { Public } \\
\text { Institutions }\end{array}$ & $\begin{array}{l}\text { Macroeconomic } \\
\text { environment }\end{array}$ \\
Germany & 12 & 11 & 5 & 15 \\
UK & 10 & 12 & 9 & 9 \\
Business competitiveness index & Sub-components: & \\
& & Company operations \& & Quality of national \\
Germany & 3 & strategy & business environment \\
UK & 6 & 2 & 4 &
\end{tabular}

Sources: World Economic Forum (2005), The Global Competitiveness Report 2004-2005. Gwartney, James and Robert Lawson (2005). Economic Freedom of the World: 2005 Annual Report. Vancouver: The Fraser Institute. Data retrieved from www.freetheworld.com.

In the indices of economic freedom, the sharpest contrast between the UK and Germany is in the 'regulation of credit, labour and business' sub-index. Here the UK ranks close to the top across 20 OECD countries and has done so for the past decade - moving from fifth to second place over the 1980s. Germany appears toward the bottom on this measure throughout the period. The countries are much closer together in their scores and ranking for the legal structure and property rights measure. Both countries rank in mid-table in the WEF's growth competitiveness index with similar scores on the technology subcomponent. Germany rates higher in the public institutions dimension, which includes infrastructure and much lower on the macroeconomic environment. Perhaps more surprising is that Germany ranks higher than the UK on the business competitiveness indicator and each of its components.

There is little dispute that British macroeconomic performance has been impressive over the past decade. As compared with Germany, UK economic strength is most apparent when measured by aggregate growth and unemployment, and the success of policy when measured by macroeconomic stability. The institutional indicators - especially for economic freedom - confirm that differences persist between the two economies. All this is in line with the prevailing characterization of these economies. However, German performance remains better in hourly productivity and the rankings in the competitiveness measures differ most on the macroeconomic (to Germany's detriment) and infrastructure 
(to the UK's detriment) components rather than on technology or the quality of the business environment.

The analysis in Section 2 indicates that in the standard closed economy model, a sustained fall in unemployment without inflationary consequences as was the case in the UK can only be the result of supply-side improvements either via reforms or through positive productivity shocks. Conversely, a sustained rise in unemployment without persistent deflation reflects supply-side deterioration. According to the standard model, supply side reforms produced falling equilibrium unemployment in the UK, which allowed aggregate demand to expand so as to maintain buoyant growth. The expansion of aggregate demand could have been due to domestic household or business sector expenditure (or net exports) either responding directly to the improvement in conditions on the supply side or indirectly, as a consequence of the operation of the macroeconomic policy response functions. With lower equilibrium unemployment, the central bank will find that as unemployment falls, inflationary pressures do not rise, allowing it to refrain from tightening policy. Equally, the fiscal authorities will be able to undertake discretionary policies to help sustain aggregate demand consistent with lower unemployment. The relationship between supply- and demand-factors is summarized by Nickell et al. (2005):

it is important to recall that unemployment is always determined by aggregate demand. As a consequence we are effectively trying to understand the long-term shifts in both unemployment and aggregate demand (relative to potential output). We emphasise this because it is sometimes thought that the fact that unemployment is determined by aggregate demand factors is somehow inconsistent with the notion that unemployment is influenced by labour market institutions. This is wholly incorrect. (p. 22).

In the case of Germany, the symmetric argument is that a persistent deterioration of the supply side was responsible for the trend increase in unemployment. Given this deterioration, macroeconomic policy had to remain tight in order to contain the upward pressure on inflation and to manage the shift of the economy to higher unemployment. If the shift in the equilibrium rate was not reflected in the measured output gap, such policy would appear to be pro-cyclical. Aggregate demand would be depressed and growth weak.

In the conventional view as summarized by the above quote, aggregate demand can only play a passive role in accounting for longer term changes in unemployment. Since only equilibrium unemployment is sustainable, fluctuations in aggregate demand will either account for temporary deviations of the economy from the equilibrium or track the path of the economy to a new equilibrium following a supply side shift. For example, if supply side conditions have improved but the response of private sector aggregate demand remains too weak, the macroeconomic policy reaction functions will produce the required stabilization around the new equilibrium. Equally, if there are exogenous shocks to aggregate demand (e.g. from the rest of the world) this may require policy to dampen or stimulate activity.

The open economy model set out in Section 2 explains how shifts in aggregate demand can take on independent significance in an open economy since there is a range of equilibrium unemployment rates - each associated with a different real exchange rate. The core of the argument is that a change in the real exchange rate implies a change in the real wage, which in turn changes conditions on the supply side. A positive aggregate demand shock will reduce unemployment and lead to a real appreciation and vice versa for a 
negative aggregate demand shock. Since real wages rise as a consequence of a real appreciation, the lower unemployment associated with the higher level of aggregate demand is sustainable. Hence, even in the absence of any supply-side improvement, an economy can experience a sustained fall in unemployment following a sustained positive aggregate demand shock. The model predicts that such a fall in unemployment is associated with an appreciation of the real exchange rate (and a deterioration in the current account) and a rise with a real depreciation (and an improvement in the current account). As noted earlier, we assume there is no immediate feedback from the changes in the current account - the medium-run equilibrium can therefore persist for some time.

Just as in the closed economy model, supply side improvements will reduce equilibrium unemployment. If a fall in unemployment is due to a supply-side improvement, it is associated with a real depreciation: competitiveness improves either because of wage restraint associated with the supply side improvement or because of enhanced productivity growth. The implications for the external balance are the opposite if the reduction in unemployment is mainly demand rather than supply driven (see Table 3 ).

Table 3. Predictions in closed and open economy versions of the New Keynesian macro model

\begin{tabular}{|c|c|c|}
\hline & Closed economy model & Open economy model \\
\hline Can an & No. & Yes. \\
\hline $\begin{array}{l}\text { exogenous shift in } \\
\text { aggregate }\end{array}$ & $\begin{array}{l}\text { Positive shift: unemployment } \\
\text { falls and inflation rises. }\end{array}$ & $\begin{array}{l}\text { Positive shift: under fixed exchange rates or } \\
\text { inflation targeting, unemployment falls and inflation }\end{array}$ \\
\hline demand shift & Aggregate demand contracts & rises. Policy is tightened. There is a new \\
\hline $\begin{array}{l}\text { medium-run } \\
\text { unemployment? }\end{array}$ & $\begin{array}{l}\text { either endogenously or via } \\
\text { policy reaction function. }\end{array}$ & $\begin{array}{l}\text { equilibrium at lower unemployment, a higher real } \\
\text { wage and an appreciated real exchange rate. The } \\
\text { external balance deteriorates. }\end{array}$ \\
\hline Can an & Yes. & Yes. \\
\hline exogenous shift in & Positive shift: inflation falls. & Positive shift: inflation falls. There is a new \\
\hline aggregate supply & Aggregate demand expands & equilibrium at lower unemployment, a lower real \\
\hline $\begin{array}{l}\text { shift medium-run } \\
\text { unemployment? }\end{array}$ & $\begin{array}{l}\text { either endogenously or via } \\
\text { policy reaction function. }\end{array}$ & $\begin{array}{l}\text { wage and a depreciated real exchange rate. The } \\
\text { external balance improves. }\end{array}$ \\
\hline
\end{tabular}

Prima facie evidence that supply side developments do not fully account for the performance of the British and German economies over the past decade and a half comes from an inspection of Fig. 4. The unemployment rate (standardized) is shown on the horizontal axis and the real exchange rate as measured by relative unit labour costs in manufacturing is on the vertical axis. A predominantly supply side interpretation of UK performance would predict the fall in unemployment to be associated with a shift to the south west. Instead, the economy moves along a path from south-east to north-west: this is consistent with a series of positive aggregate demand shocks. Consistent with some improvement on the supply side is the apparent shift to the left in the relationship between the real exchange rate and unemployment, but that is far from the only factor involved as shown by the major real appreciation. 
Figure. 4 The evolution of the real exchange rate and unemployment in UK and Germany 1991-2005
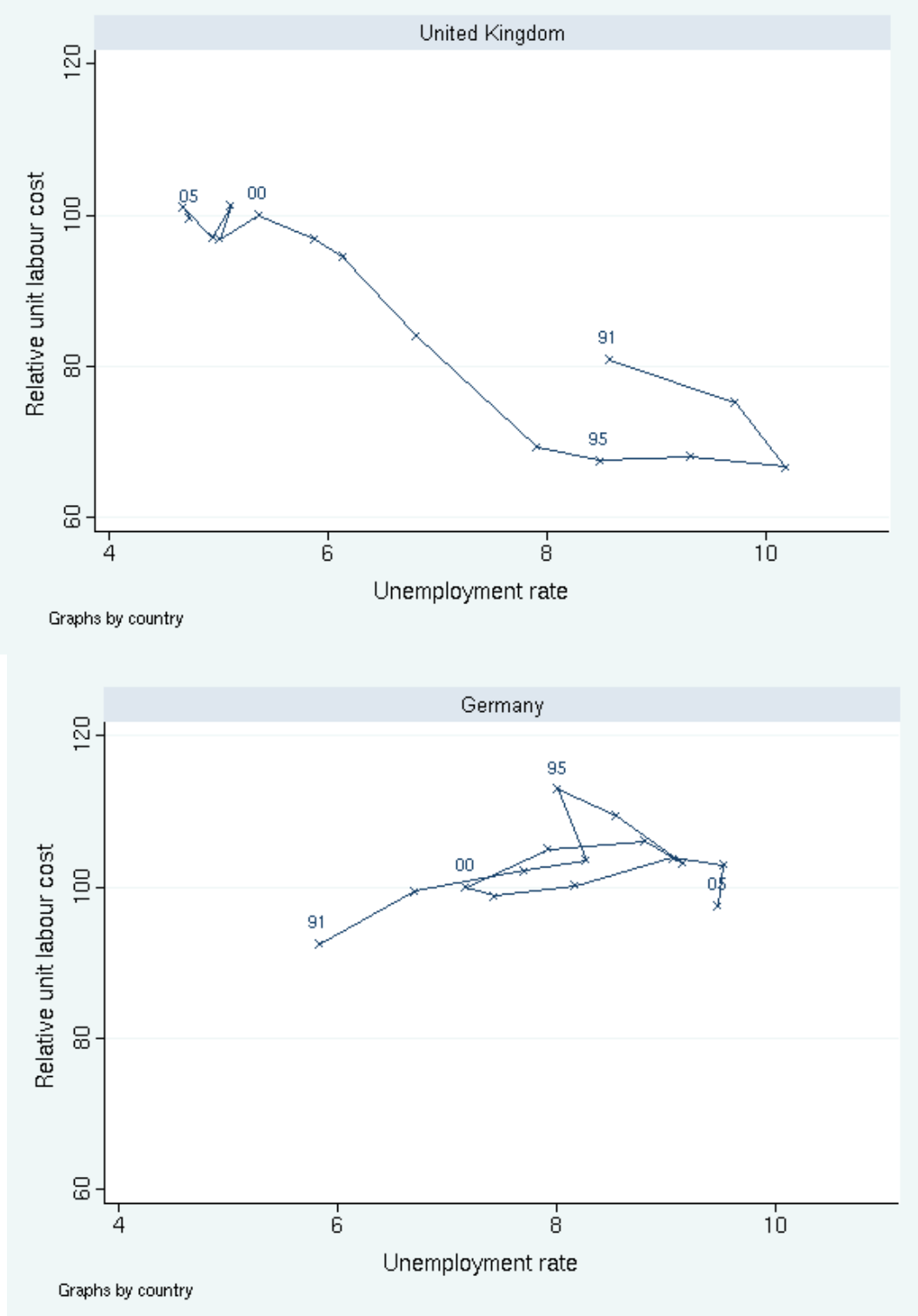

Source: OECD Economic Outlook Database 2006

Note: RULC=100 in 2000; an increase in RULC is a real appreciation.

Turning to Germany, a supply side explanation for rising unemployment would predict that the rise in unemployment would be associated with a real appreciation - a move to the north-east - with a combination of wage pressure and poor productivity performance depressing net exports. However, the impression from Fig. 4 is that the real exchange rate has moved within a narrow range. When combined with the evidence that net exports have been strong (not only relative to other components of aggregate demand in Germany but also in international comparison), this casts doubt on the supply side story as the dominant one. The alternative hypothesis as argued in Section 2, is that with wage-setting led by tradable sector unions in Germany, wage growth has been oriented toward maintaining the real exchange rate, and shifts in aggregate demand lie behind the horizontal path. 
The success with which the core labour system has been restructured in Germany is reflected in the recovery of profitability especially in manufacturing but also in the broader business sector. Figure 5 shows long time series for the net profit share. There is a break in 1991 between the series for West Germany and for unified Germany. Approximately half of the drop in the profit share at this point is due to the incorporation of East Germany and the other half is due to a change in the definitions used in the national accounts.

Figure 5. Long-run Behaviour of Net Profit Shares, Germany 1950-2005

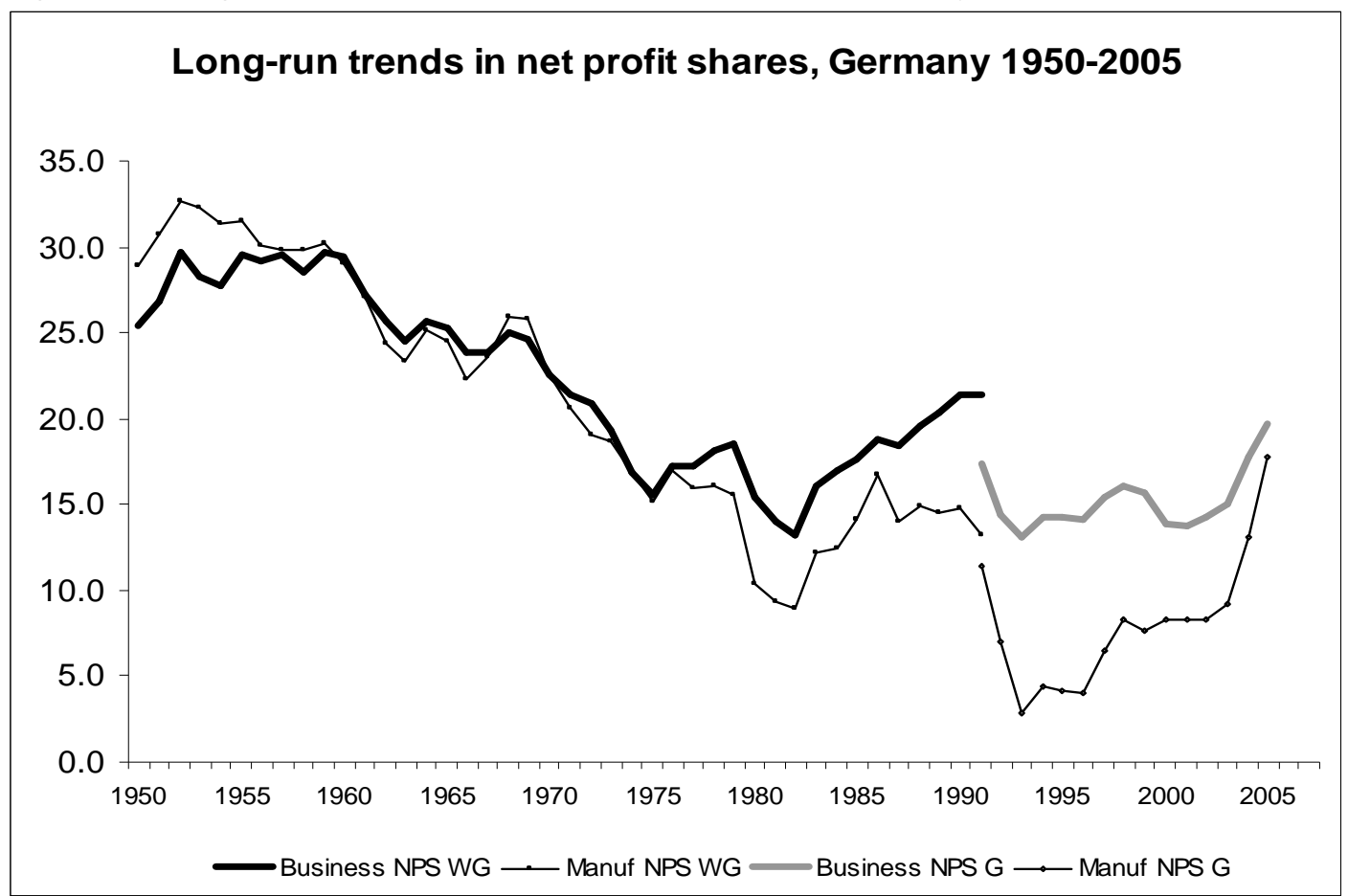

Source: German National Accounts, various years. Own calculations.

In the rest of this section, we set out the contrasting behaviour of the components of aggregate demand in Germany and the UK, concentrating on the post 1990 period. We then turn to the supply side and evaluate some existing evidence about the extent to which supply side changes are estimated to account for trends in unemployment in both countries.

\section{Aggregate demand and employment: Germany and the UK compared}

We begin by comparing the decomposition of GDP growth according to its components in the UK and Germany. Fig. 6 shows for each economy the growth of real GDP and the contribution to growth of four key components: private sector consumption plus housing; private sector fixed investment (excluding housing), government consumption and investment, and net exports. Each series is presented as the 3-year moving average. The top panel of Fig. 6 for the UK, shows high and stable growth of GDP throughout the whole period from the early 1990s. There was a consistently high positive contribution to the growth of GDP from the household sector. The contribution of government expenditure was the mirror image of that of business sector investment: the sustained investment boom in the second half of the 1990s was mirrored by contracting public expenditure and the reverse characterized the 2000s. The real appreciation of the exchange 
rate from 1997 (see Fig. 4) was followed by a deterioration of net exports, which remained as a negative influence on the growth of demand for the remainder of the period.

As the lower panel indicates, German growth was much weaker than in the UK through the 1990s. The first notable feature is the low and declining contribution of government expenditure to growth. This contributed less than $0.5 \%$ p.a. to real growth each year and became negative from the early 2000s. Second, the contribution of household expenditure fell sharply from 2000, itself becoming negative at about the same time as did government expenditure. Third, net exports made a positive contribution over most of the period and dominated as the source of positive demand growth after household expenditure collapsed in the early 2000s. The contribution of private investment fluctuated within a narrow band from -0.5 to $1 \%$ per annum.

Figure 6. Contributions to the growth of real GDP
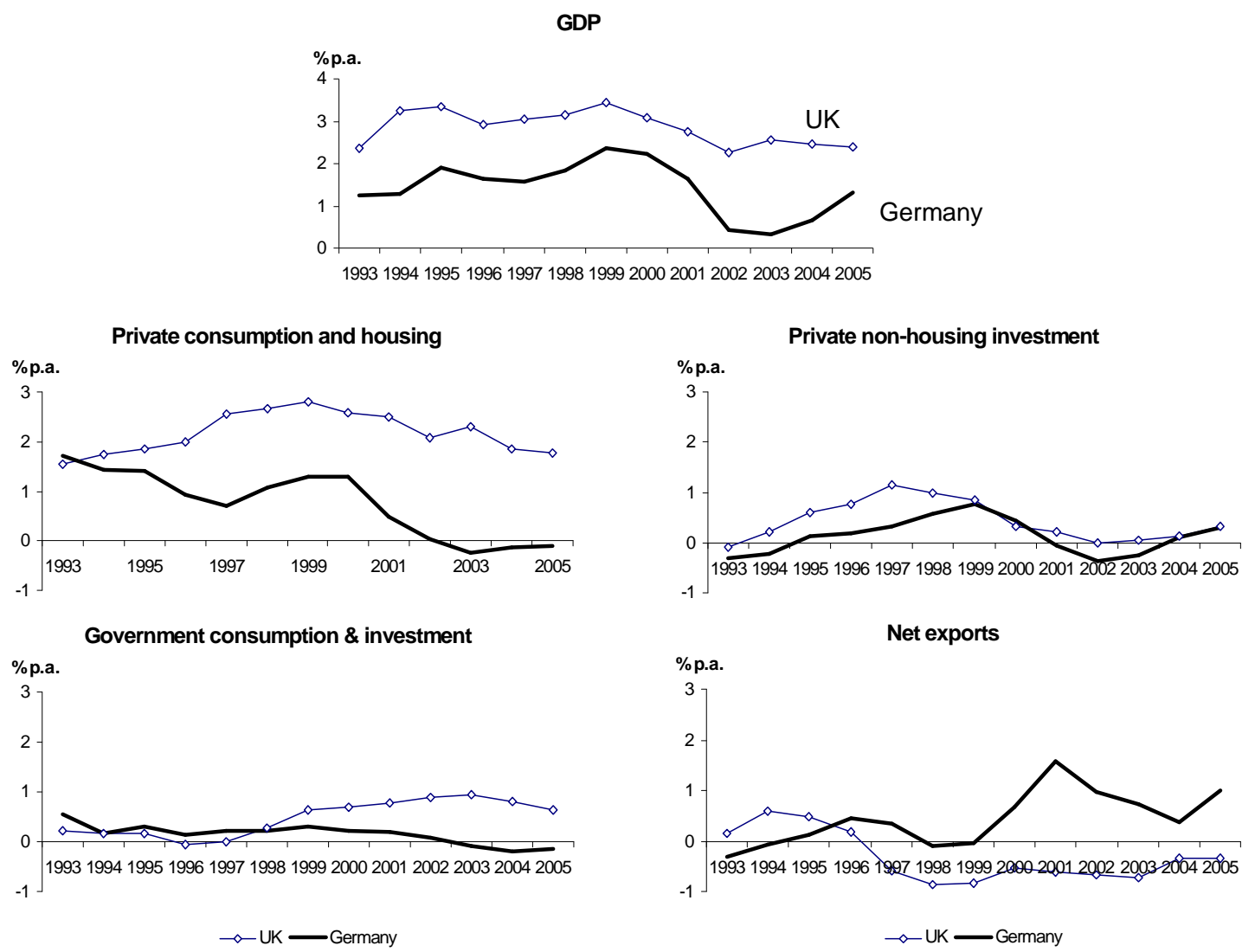

Source: OECD National Accounts Database June 2006

Notes: Contributions to the growth of constant price GDP (3 year moving average). The contributions do not add up to GDP growth because of the omission of stock-building, a statistical discrepancy and the treatment of government investment in housing. Data for 2006 are OECD forecasts.

The contrast in aggregate demand behaviour between the two economies is stark. Domestic aggregate demand was strong throughout the period in the UK, with the government sector appearing to play a key role in stabilizing and sustaining it. Particularly in the second half of the period, the simultaneous weakness of private and government components of domestic demand in Germany is striking. The left panel of Fig. 7 shows the evolution of the household savings ratio (as a percentage of disposable 
income) over the period in both countries. The pattern for Germany is a shallow U-shape, with the trough at the turn of the century. By contrast, there was a dramatic fall in the UK savings rate beginning around 1997. An important structural difference between the two economies over this period that is linked to consumption and savings behaviour is the evolution of house prices. As the right panel of Fig. 7 indicates, house price trends in Germany and the UK have been opposite in the last 15 years. Since 1995, real house prices in the UK have risen by an annual rate of more than $8 \%$ whereas they have fallen by more than $2 \%$ p.a. in Germany. ${ }^{11}$

As argued in Section 1, the specific characteristics of the German labour market are likely to have played a role here. Vocational qualifications play a far greater role in the German labour market than elsewhere. Through the apprenticeship system workers tend to acquire industry competences, which are supplemented by firm-specific skills. Job tenures are on average longer than in other countries. The consequence is that the 'mid-career' labour market is much thinner than in an economy like the UK. The prospect of labour market reforms that increase the cost of job loss is therefore likely to have a greater effect in boosting savings than, for example, in the UK.

Figure 7. Household savings ratio and real house price changes, UK and Germany
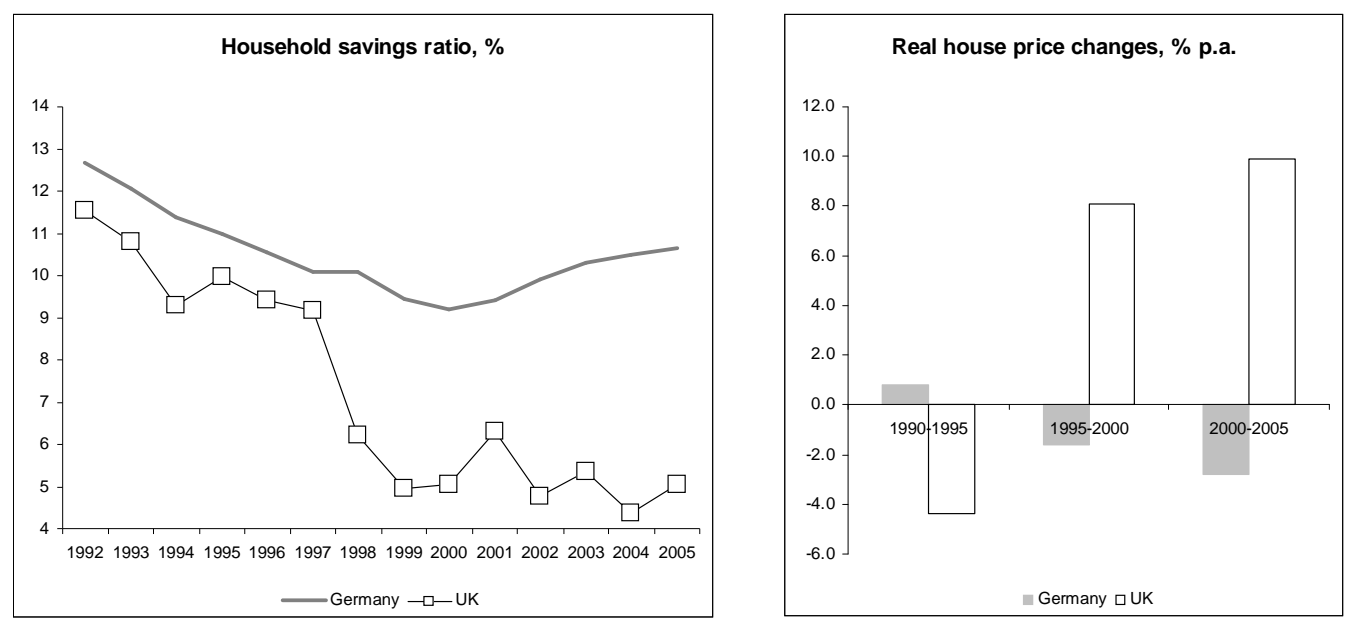

Source: The household savings ratio comes from OECD National Accounts database; the house price data is from OECD Economic Outlook 79, p. 18

From the behaviour of government expenditure in the UK shown in Fig. 5, it appears that discretionary fiscal policy was used to sustain aggregate demand in the early 2000s. This impression is reinforced by the data in Fig. 8, which compares the path of the discretionary fiscal stimulus (as measured by the change in the cyclically adjusted primary government balance) relative to the output gap in Germany and the UK. By contrast, discretionary fiscal policy appears to have been systematically pro-cyclical in Germany -

\footnotetext{
${ }^{11}$ The OECD estimated the overvaluation of house prices in the UK in 2004 at $32.8 \%$ (using the price to rent ratio, which was most recently at its 35 year average in 2000) and undervaluation in Germany in 2004 at $25.8 \%$ (also relative to 2000 - although the price to rent ratio has been declining there since the 1980s). (OECD, 2005. Economic Outlook 78 p. 136).
} 
reducing fiscal stimulus when the economy was operating below potential for much of the period, e.g. tightening in parallel with weakening household expenditure both in the mid 1990 s and in the early 2000 s.

Figure 8. Indicator of discretionary fiscal policy

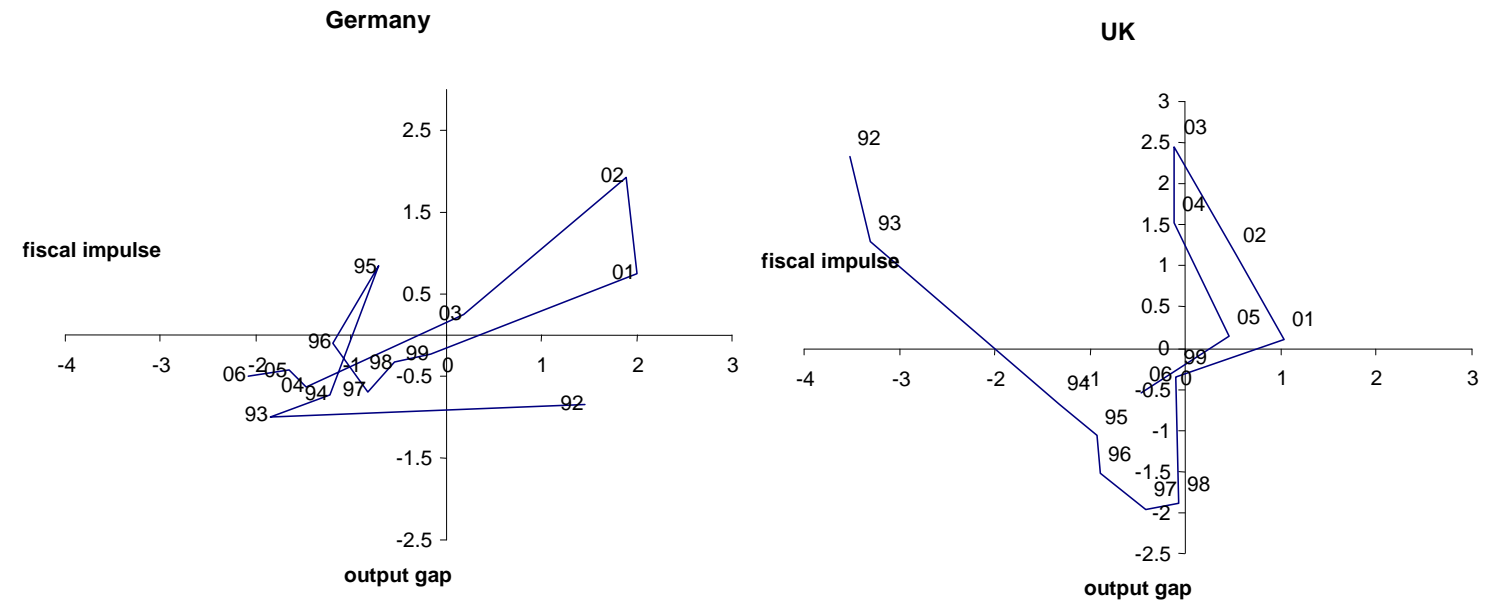

\begin{abstract}
Source: OECD Database; Fiscal impulse is the change in the cyclically adjusted primary deficit from the previous year (corrected for the receipts from the auctions of telecoms spectra).
\end{abstract}

We can also trace the impact of the differential role played by aggregate demand in Germany and the UK by examining the changes in employment in different industries. Table 4 shows the percentage point contributions to the growth of the employment rate in Germany and the UK from 1995 to 2003 . As is well known, the employment rate in the UK grew much more than in Germany - a difference of 5 percentage points (row 10). As the first three rows demonstrate none of this difference arises from the tradable goods sector, where the decline in each country was very similar (agriculture and mining fell by more in Germany and manufacturing by less). Perhaps more surprising is that finance and business services (row 7) contribute nothing to explain the weaker employment performance in Germany. Major differences between the two countries were in job creation in distribution (retail, wholesale, hotels \& catering) and in public administration, health and education. In each case, about $1 \%$ point of the difference in employment growth is accounted for. Above all, it is in construction that the employment patterns differed: falling by $1.7 \%$ points in Germany and rising by 0.5 in the UK.

The slow growth of household expenditure was not reflected in greater employment loss in the traded goods sector in Germany because of the offsetting strength of export demand. However, this was not the case in distribution: it is here that the differences in household spending behaviour between the UK and Germany documented above were reflected in job creation. ${ }^{12}$ Equally, the public sector expenditure growth in the post 2000 period in the UK contributed substantially to the employment differences. The differences in

\footnotetext{
${ }^{12}$ For a detailed cross-country analysis of the role of demand in accounting for employment differences in services, see Glyn et al. 2004.
} 
construction were due in part to the unwinding of the infrastructure boom associated with unification in Germany but also to the absence in West Germany of a revival of residential investment.

Table 4. The industry composition of changes in the employment rate, 1995-2003

$\begin{array}{llll}\text { Industry } & \text { Germany } & \text { UK } \\ 1 & \text { Agriculture, forestry \& fishing } & -0.4 & -0.3 \\ 2 & \text { Mining and energy } & -0.3 & -0.2 \\ 3 & \text { Manufacturing } & -1.3 & -1.5 \\ 4 & \text { Construction } & -1.7 & 0.5 \\ 5 & \text { Distribution } & 0.9 & 1.7 \\ 6 & \text { Transport \& communications } & -0.1 & 0.5 \\ 7 & \text { Finance, business services } & 3.1 & 3.0 \\ 8 & \text { Public administration, health, education } & 1.2 & 2.2 \\ 9 & \text { Other services } & 0.7 & 1.0 \\ 10 & \text { Total } & 2.0 & 7.0\end{array}$

Source: Calculated from Groningen Growth and Development Centre, 60-Industry Database, October 2005, http://www.ggdc.net updated from O'Mahony and van Ark (2003)

Note: The table shows the absolute change in employment 1995-2003 divided by the 2003 population of working age.

\section{Accounting for changing unemployment: supply side evidence}

Within the context of the mainstream model, i.e. where medium-run trends in unemployment are the outcome of supply side shifts in equilibrium unemployment, a large number of empirical studies have been carried out into the relationship between changes in unemployment and in labour market institutions. More recently, this approach has been extended to include the role of product market regulation.

Recent systematic surveys of the accumulated evidence are available in Baker et al. $(2005)^{13}$, Blanchard (2005) and in Bassanini and Duval (2006) ${ }^{14}$. Baker et al. emphasize the lack of robustness of the estimated effects of changes in labour market institutions on unemployment in OECD countries, Bassanini and Duval present a more positive view of what has been learnt and Blanchard's assessment lies in between. ${ }^{15}$

We use estimates from two recent studies in this tradition to highlight the implications for the diagnosis of unemployment trends in the UK and Germany. The first is Nickell et al. (2005, hereafter NNO) and the second is Bassanini and Duval (2006, BD). Both studies include the same 20 OECD countries. The Nickell et al. study uses a longer time series from 1960 to 1995 whilst Bassanini and Duval use improved data for some of the labour market institutions variables and a period from 1982-2003. In both studies the estimation techniques make use of the within country variation in institutions (along with some controls for shocks) to explain trends in unemployment. The labour market institution variables included are measures of the replacement rate, the tax wedge, union density, employment protection legislation, and coordination in wage setting. The studies vary in their treatment of the replacement rate and benefit duration. NNO include a number of interaction terms between the institutional variables, use the change rather than the level of union density and also include the real interest rate. BD include the newly constructed

\footnotetext{
${ }^{13}$ Updated in Howell et al. 2006.

${ }^{14}$ Also reported in OECD (2006) Economic Outlook.

${ }^{15}$ For a trenchant critique of macro studies of this kind, see Heckman and Pagés (2003).
} 
OECD measure of product market regulation. In their base-line regression, BD use the output gap as a catch-all for macroeconomic shocks and NNO use four separate shocks.

In spite of these differences, the results are fairly similar (NNO Table 5, column 1; BD Table 1.2, column 2): employment protection legislation is not significant in either study, unemployment benefit variables are positive and significant, coordination is negative and significant, and the tax wedge is positive and significant. NNO find a positive and significant effect on unemployment of the change in union density, but the level is not significant in $\mathrm{BD}$. The index of product market regulation is positive and significant in $\mathrm{BD}$, as is the real interest rate in NNO.

The results for our two countries from simulating the NNO specification, which includes lagged unemployment and country-specific time trends, are quite instructive. The dynamic simulation tracks the path of actual unemployment reasonably well (top panel of Fig. 9). The lower panel of Fig. 9 compares the standard dynamic simulation for each country with the simulated path when institutions are held at their values in 1960. The graph for the UK shows that (based on the regression coefficients) deleterious changes in institutions from the 1960s through to the end of the 1970s predict rising unemployment during this period. The narrowing of the gap between the standard and the fixed institutions simulations thereafter reflects the effect of an improvement in the institutional variables.

Figure 9. The role of changing institutions in explaining unemployment trends: simulations from Nickell et al. (2005)
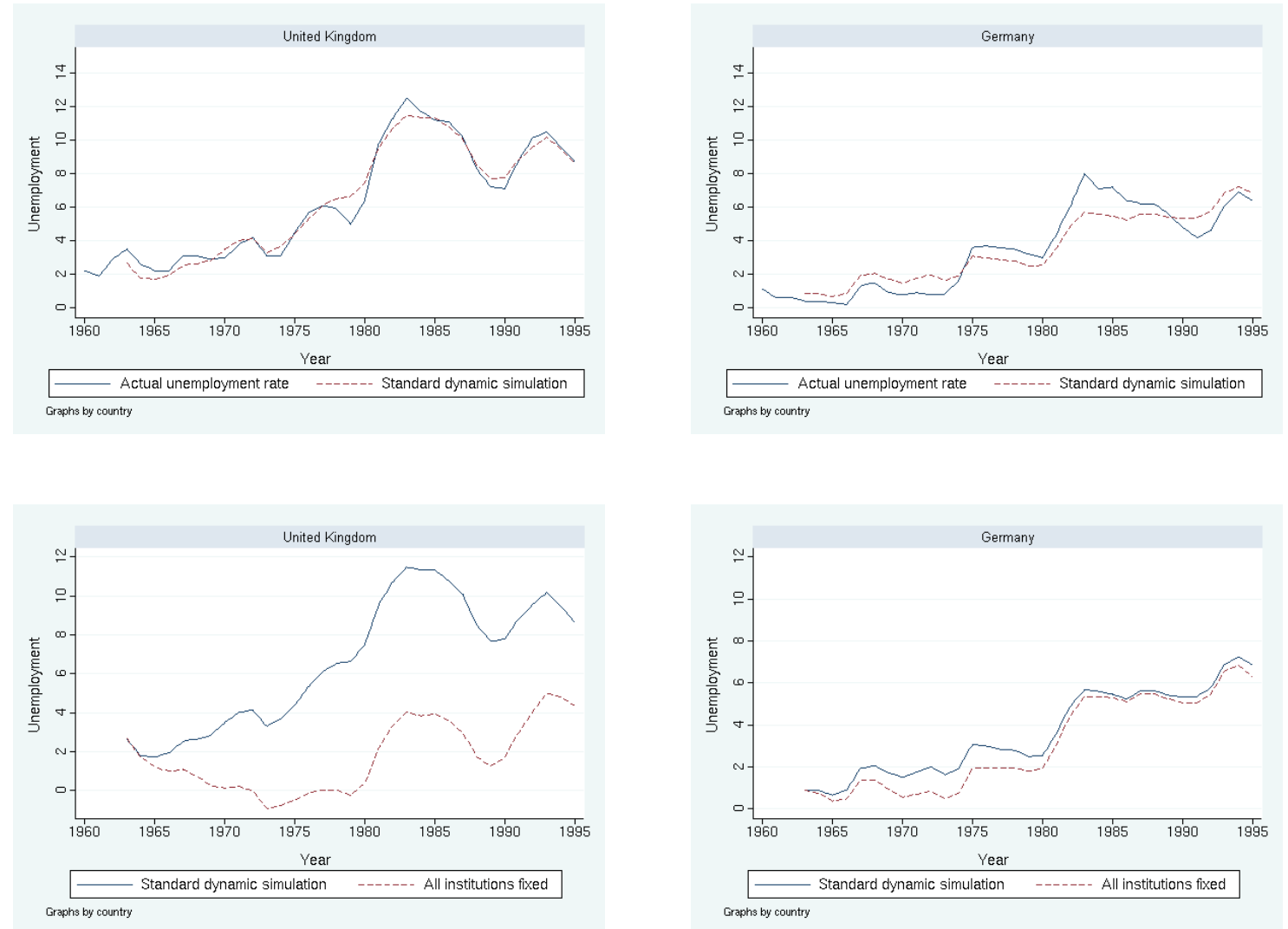

When the same experiment is repeated for Germany, the results are different. Although changing institutions predict a modest part of the rise in unemployment in the 1960s and 1970s, they predict nothing thereafter. 
Turning to the Bassanini and Duval baseline regression, which focuses on the post-1983 period, we can decompose the predicted changes in unemployment for the UK and Germany by using the estimated coefficients from the panel regression and applying them to the changes in the institutional variable for each country.

Table 5 presents the results: the analysis for Germany is divided into pre- and postunification periods. The variables for which the coefficients are not significant are shown in italics. The mechanical application of the estimated coefficients to the institutional changes in Germany suggests that unemployment should have fallen in both periods, with institutional improvements - especially product market deregulation - driving the reduction since 1993. The evolution of each of the supply side variables for Germany and the UK is shown in the appendix.

Parallel to the findings from the NNO exercise, the BD estimates are more successful in accounting for the fall in unemployment in the UK than for its rise in Germany. For the UK, the big predicted contributions come from the reduction in the tax wedge and the decline in product market regulation. The equation attempts to account for deviations of actual from equilibrium unemployment by including the output gap as a regressor and once this is taken into account, the equation predicts a substantially larger fall in unemployment in the UK than occurred (a fall of 9.3 points as compared with the fall of 5.5 points observed).

Table 5. Accounting for the change in unemployment in Germany and the UK using the estimated coefficients from Bassanini and Duval (2006)

\begin{tabular}{|c|c|c|c|c|c|c|c|}
\hline & \multirow{2}{*}{$\begin{array}{l}\text { Change } \\
\text { 82-90, } \\
\text { Germany }\end{array}$} & \multirow{2}{*}{$\begin{array}{l}\text { Change } \\
93-03 \text {, } \\
\text { Germany }\end{array}$} & \multirow{2}{*}{$\begin{array}{l}\text { Change } \\
82-03 \text {, UK }\end{array}$} & \multirow{2}{*}{$\begin{array}{l}\text { Bassanini } \\
\text { Duval } \\
\text { coefficients }\end{array}$} & \multirow{2}{*}{$\begin{array}{l}\begin{array}{l}\text { Contribution } \\
\text { change }\end{array} \\
\text { Germany, } \\
82-90\end{array}$} & \multicolumn{2}{|c|}{ to unemployment } \\
\hline & & & & & & $\begin{array}{l}\text { Germany, } \\
93-03\end{array}$ & $\begin{array}{l}\text { UK, } \\
82-03\end{array}$ \\
\hline $\begin{array}{l}\text { Average } \\
\text { replacement } \\
\text { rate }\end{array}$ & -0.9 & -0.6 & -6.6 & 0.1 & -0.1 & -0.1 & -0.8 \\
\hline Tax wedge & 0.1 & -0.2 & -12.5 & 0.3 & 0.03 & -0.1 & -3.5 \\
\hline Union density & -3.8 & -8.6 & -18.2 & -0.03 & ns & ns & ns \\
\hline $\begin{array}{l}\text { Employment } \\
\text { protection }\end{array}$ & 0.0 & -0.9 & 0.1 & -0.3 & ns & ns & ns \\
\hline $\begin{array}{l}\text { Product } \\
\text { market } \\
\text { regulation }\end{array}$ & -0.7 & -2.4 & -3.4 & 0.6 & -0.4 & -1.5 & -2.1 \\
\hline $\begin{array}{l}\text { High } \\
\text { corporatism }\end{array}$ & 0.0 & 0.0 & 0 & -1.4 & 0.0 & 0.0 & 0.0 \\
\hline \multirow[t]{4}{*}{ Output gap } & 8.2 & -0.1 & 6.1 & -0.5 & -4.0 & 0.1 & -2.9 \\
\hline & & & \multicolumn{2}{|c|}{ Predicted change in $U$} & -4.4 & -1.5 & -9.3 \\
\hline & & & \multirow{2}{*}{\multicolumn{2}{|c|}{$\begin{array}{l}\text { Predicted by policies, i.e. } \\
\text { excluding output gap } \\
\text { Actual change in } U\end{array}$}} & -0.5 & -1.6 & -6.3 \\
\hline & & & & & -1.8 & 1.4 & -5.5 \\
\hline
\end{tabular}

Note: The predicted changes exclude the impact of changes in variables where the coefficients were not significant (ns). Columns may not add exactly due to rounding.

Macro policy and supply-side reforms: comparing the UK and Germany 
As we have seen, Germany has implemented supply side reforms that should - according to the cross-country evidence - have produced lower unemployment. According to the standard model, these supply side improvements would have enabled aggregate demand to evolve in line to support a higher growth rate and lower unemployment. In this section we look at a number of the puzzles raised by this finding. First, we document the more limited activism of macroeconomic policy in Germany than in most other OECD economies. Second, we present some evidence that reform intensity has been relatively strong in Germany (as compared with other OECD economies). Third, we identify features of the German economy that may explain why the supply side reform effort has had such a meagre pay-off. Bringing these findings together in the context of the discussion in Sections 1 and 2, we can propose a hypothesis to explain why domestic aggregate demand in Germany has been so weak and why macroeconomic policy has done so little to contribute to stabilization.

Has less use been made of stabilization policy in Germany than elsewhere?

Recent work by the OECD confirms that the use of counter-cyclical policy appears to vary systematically across groups of countries in a way that is consistent with the predictions of Section 2. ${ }^{16}$ Fig. 10 shows the contemporaneous correlation between the change in the cyclically adjusted primary balance and the output gap over the period 1981-2005 for the countries that now make up the euro-zone, the Nordic countries and 'other' OECD. Finland is included with the Nordic group. The results indicate that fiscal policy has tended to be pro-cyclical in the euro-zone countries but counter-cyclical in the two other groups. As suggested in Section 2 one explanation for this may lie in the political economy of macroeconomic policy making. Discretionary stabilizing policy is easier for governments to use both in the Nordic countries with encompassing institutions and in the liberal economies that dominate the 'other OECD' group than in the economies with coalition governments and large wage-setters that are prevalent in the euro-zone group.

Figure 10. Is discretionary fiscal policy counter-cyclical?
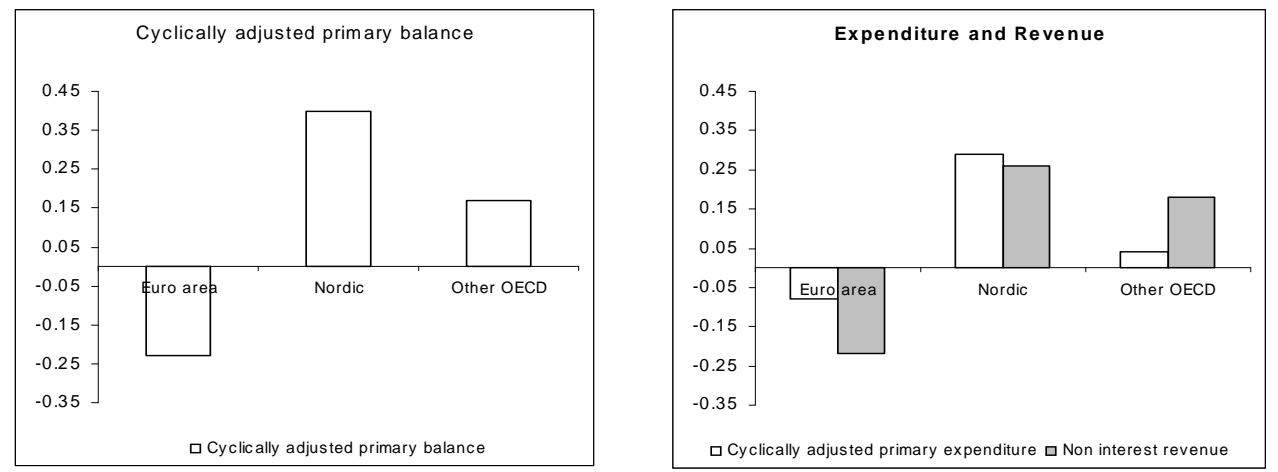

Source: Data from OECD Economic Outlook 79 2006, p.32. Additional detail from Cotis (2006).

Note: Each bar shows the contemporaneous correlation between changes in the cyclically adjusted primary balance and the output gap over the period 1981-2005. Germany (1991-2005). The sign has been changed for primary expenditure in the panel with expenditure and revenue so that a positive correlation indicates countercyclicality. The euro area excludes Finland, which is included in the Nordic group (with Denmark, Norway, and Sweden). Other OECD includes US, UK, Japan, Canada, Australia, South Korea, New Zealand and Switzerland.

\footnotetext{
${ }^{16}$ Aghion and Marinescu (2006) also report evidence consistent with these findings.
} 
How intensive has the reform effort been in Germany?

One way to standardize the assessment of the policy reform effort that has taken place is to use the indicators created by the OECD. Starting from the influential Jobs Report in 1994 followed by their assessment of progress in 1999 and the introduction in 2005 of annual reports of policy reforms in the series Economic Policy Reforms: Going for Growth, the OECD has developed an indicator based approach to the measurement of the reform effort across countries.

Table 6 provides a summary of the OECD's aggregate measure of labour market reform and includes all legislated reforms to the middle of 2004. This shows that Germany has been very active (only Denmark, the Netherlands and Finland rank higher) in the adoption of labour market reforms. The score shown in the table refers to the number of actions taken: the details of how the German reforms were scored are shown in the appendix. The UK has been less active, which reflects a smaller shortfall from an implicit benchmark for a 'reformed' labour market. Table 7 indicates that Germany has implemented reforms across all seven categories, whereas the UK has concentrated reform in active labour market measures and tax and benefit reform. German reforms have all been in the recommended direction.

Table 6. The intensity of labour market reforms undertaken between 1994 and 2004

$\begin{array}{lll} & \text { Score } & \text { Rank (out of 30 } \\ & \text { OECD countries) } \\ \text { Germany } & 23.9 & 4 \\ \text { UK } & 16.7 & 11\end{array}$

Source: Brandt, Burniaux and Duval (2005). Table 8, p. 56. The score relates to the number of actions taken. See the Appendix for more details.

Table 7. Labour market reform intensity from 1994 to 2004 by individual indicators

$\begin{array}{llllllll} & \text { EPL } & \begin{array}{l}\text { Unemp. } \\ \text { Benefits }\end{array} & \begin{array}{l}\text { Working } \\ \text { time } \\ \text { flexibility }\end{array} & \begin{array}{l}\text { Early } \\ \text { Retirement }\end{array} & \begin{array}{l}\text { Wage } \\ \text { formation } \\ \&\end{array} & \text { ALMP } & \begin{array}{l}\text { Taxes } \\ \&\end{array} \\ & & & & \begin{array}{l}\text { industrial } \\ \text { relations }\end{array} & & \begin{array}{l}\text { social } \\ \text { security }\end{array} \\ \text { Germany } & 16.7 & 19.2 & 16.7 & 25.0 & 9.1 & 57.7 & 12.5 \\ \text { UK } & -10.0 & 11.5 & 0.0 & 25.0 & -9.1 & 50.0 & 56.3\end{array}$

Source: Brandt, Burniaux and Duval (2005). Table 8, p. 56. Measures introduced contrary to the recommendations of the Jobs Study are scored with a negative number. The score relates to the number of actions taken. See the Appendix for more details.

Can reform effort affect private sector aggregate demand?

We have shown that aggregate household expenditure has behaved quite differently in Germany as compared with the UK over the past decade and especially since 2000 . One hypothesis is that the nature of the reform programme debated and pursued in Germany has created uncertainty about job security, which has led to an increase in precautionary savings. One of the channels through which the labour market reforms, such as lower replacement ratios and shorter duration of unemployment benefit, are supposed to have 
their employment enhancing supply-side effects is by increasing the cost of job loss. Reductions in employment protection are aimed at reducing the cost of hiring by making it easier to fire workers. Whilst there has been considerable debate about whether reducing employment protection is likely to affect investment by workers and firms in job matches, less has been said about the potential impact on savings behaviour of such actual and prospective changes in an economy like Germany where investment in specific skills is important. ${ }^{17}$ The prospect of labour market reforms that increase the cost of job loss is therefore likely to have a greater effect in boosting savings in Germany than, for example, in the UK.

This effect is likely to be reinforced by the fact that in contrast to the Nordic countries where two-earner households are the norm, the German labour market and welfare state are characterized by provisions that encourage single earner households and make it difficult for women with children to work. Recent cross-country data for 20 OECD countries (left hand panel of Fig. 11) illustrates a positive - although not significant correlation between the female employment rate and fertility. The correlation in 1980 was weakly negative. The right hand panel highlights that the Nordic countries have increased (or maintained very high) employment rates and increased fertility rates since 1980. Germany has both a low female employment rate and low fertility.

Figure 11. Fertility and female employment rates: cross- country comparisons

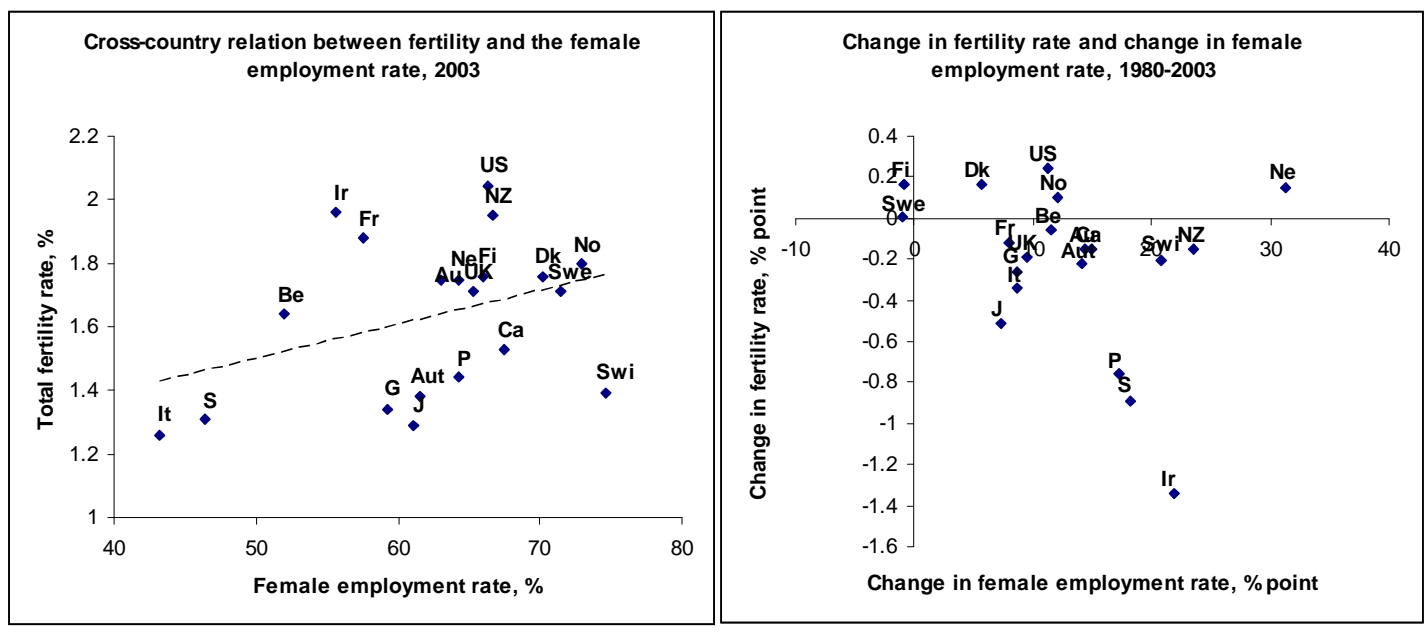

Source: OECD data.

Notes: The female employment rate is employment as a percentage of the population aged 15-64

Variations in arrangements exist across the Nordic countries to promote labour market participation and fertility - e.g. in Finland, generous allowances are paid to women who have children and decide to remain at home while the children are very young. Their jobs are held open for them. In Sweden, families with young children have generous maternity and paternity leave, both parents tend to remain in employment and make use of high quality child-care (e.g. Hoem, 2005). Both arrangements have been associated with a

\footnotetext{
${ }^{17}$ Some preliminary evidence that announced reforms to the pension system have measurable effects on savings (and labour supply) is provided in an analysis of German data (see Giavazzi and McMahon, 2005).
} 
revival of fertility rates along with continued high employment rates for women. Such policies presumably help to maintain the growth of household expenditure by reducing the household income risk as compared with the single bread-winner paradigm in Germany and more broadly by reducing pessimism about the future financing of the welfare state including pensions. For example, in the sharp post 1990 recession in Finland, families appear to have responded to the weakness of the labour market by shifting the timing of family formation: women received generous out-of-work benefits whilst looking after young children at home. ${ }^{18}$

A second channel through which the reform effort in Germany may have affected domestic aggregate demand is through the impact of actual and prospective wage restraint in depressing consumption expenditure. As noted in the introduction, German exports have performed well over the period. Recent studies indicate that improved cost competitiveness and the concentration of German export markets in rapidly growing foreign markets have both played a role. There was also an 'unexplained' positive trend presumably reflecting unmeasured quality improvements. ${ }^{19}$ In contrast to small open economies where the aggregate demand response to a change in unit labour costs is dominated by its effect in raising net exports, the spread of wage restraint across the economy in Germany where tradables are a much smaller share of the economy is likely to have had a bigger depressive effect on consumption demand (in the presence of liquidity constrained households). However, more detailed analysis is required of the channels through which wage restraint affects demand - via net exports, consumption and investment.

\section{Some lessons for the design of economic reforms in Germany}

We have argued that the behaviour of aggregate demand can play a role in accounting for persistent changes in unemployment across the advanced economies. Whereas in the standard (closed economy) model, aggregate demand plays an accommodating role in the medium run - expanding or contracting to secure consistency with the supply conditions the recent experience of the UK and Germany suggests that swings in aggregate demand have driven medium run unemployment trends. Although unemployment at its current low rate may not be sustainable in the long run in the UK as the consequences of the apparent imbalances between the domestic and external sides of the economy force a rebuilding of domestic savings, there seems little doubt that a better functioning supply side has been achieved and with it the prospect of relatively satisfactory labour market performance over the medium run. Equally important was the gradual adoption through the 1990s of a macroeconomic policy framework that actively stabilizes the growth of aggregate demand. Although most attention has been paid to the role of the Bank of England, we have shown that fiscal policy has been the key to sustaining aggregate demand in the UK in the period since 2000. However, the undisputed success story of recent British economic performance is in the financial services sector where other reforms - the abolition of exchange controls and the so-called Big Bang liberalization of financial markets - were the key to allowing the UK's nascent comparative advantage in this sector to flourish. Concerns for policy makers in the UK are centred on the decline in household savings and the problems with pension provision, the relatively weak innovation performance of the economy, and the deficits in education and transport infrastructure.

\footnotetext{
${ }^{18}$ For more details including a comparison with Sweden, see Vikat (2004).

${ }^{19}$ Allard et al. (2005).
} 
More generally, a substantial number of OECD countries appear to have evolved relatively successful combinations of policies and institutions to sustain the growth of aggregate demand in line with a supply-side that is able to deliver high labour utilization and low unemployment. Thirteen of the 20 OECD economies had an estimated structural unemployment rate of less than 6\% in 2004-5: an Anglo-Saxon group (Australia, UK, US, Ireland, New Zealand), a Nordic group (Denmark, Norway and Sweden) plus Austria, Japan, Netherlands, Portugal and Switzerland. ${ }^{20}$ Too little attention has been paid to understanding the variation in supply-side reforms in the 'successful' economies, to understanding how aggregate demand has evolved and been managed in successful and unsuccessful ones and how the political system influences the flexibility with which demand management measures can be used.

The variation in reform packages implemented across countries (and even within the Nordic group) and the potential effect of announced reforms on savings decisions and therefore on macroeconomic activity, suggests that the impact of a given change in labour market institutions on medium run unemployment will differ across countries. It is therefore not surprising that the dominant empirical approach of estimating cross-country panel regressions for unemployment, which is based on the assumption of common coefficients on proxies for labour and product market institutions, has proved unrobust.

In addition to taking account of cross-country heterogeneity, the proper evaluation and hence design of the prospective impact of policy reforms should include their impact on much longer term decisions such as human capital accumulation. As an example, a recent study models the long term life cycle effects of two different labour market reforms in a structural model implemented using detailed microeconomic data on German men (Adda et al. 2006). The model is one where jobs take time to locate and in which wages depend on the quality of the match between firm and worker, experience and tenure. The policy comparison is between the introduction of an earned income tax credit (EITC) as in the US and a reform to unemployment insurance (replacing earnings-related unemployment insurance with a flat rate) as introduced in the UK.

The exercise reveals that although both policies have their intended positive effect on employment, they have implications for training and job mobility that may not have been anticipated. Under the EITC, it is estimated that training would fall by seven percentage points whilst the impact on the employment rate is modest at about one percentage point. By contrast, the unemployment benefit reform is predicted to reduce training by more but to also to raise employment by more. The intuition is fairly straightforward. To take one example, under the unemployment benefit reform, training rates are depressed for all types of workers by the disappearance of the anticipated increased benefit when unemployed for those who are trained. This outweighs the effect of lower benefits under the policy change in inducing non-apprentices to train. Employment is boosted because unemployment "pays less'. In both cases, the estimated quality of the worker-firm match declines following the implementation of the policy. Since the job match is worth less, workers search less hard.

${ }^{20}$ OECD Economic Outlook 79 Appendix Table 22. 
Table 8. Model simulation: earned income tax credit and unemployment benefit reform

\begin{tabular}{|c|c|c|c|c|}
\hline & $\begin{array}{l}\text { Effect } \\
\text { employment } \\
(\%)\end{array}$ & $\begin{array}{l}\text { Effect on training (\% } \\
\text { trained as } \\
\text { apprentices) }\end{array}$ & $\begin{array}{l}\text { Effect on quality of } \\
\text { employee- } \\
\text { employer match } \\
\text { (relative to existing } \\
\text { baseline) }\end{array}$ & $\begin{array}{l}\text { Life-cycle effect } \\
\text { on utility } \\
\text { (relative to } \\
\text { existing baseline) }\end{array}$ \\
\hline EITC & $+1 \%$ points & $-7 \%$ points & $-4 \%$ & $-1.4 \%$ \\
\hline UB reform & $+4-5 \%$ points & $-11 \%$ points & $-3.2 \%$ & $+2.5 \%$ \\
\hline
\end{tabular}

\section{Conclusions}

The aim of this paper is to contribute to the debate about the conventional diagnosis of Germany's poor economic performance, which focuses on supply-side weaknesses and the need for more vigorous and deeper reforms especially to make low-skill private service sector labour markets more flexible. We can summarize the standard view as follows:

- Medium-run unemployment is determined entirely by supply-side forces. Hence robust growth and falling unemployment in the UK is the outcome of supply-side reforms and weak growth and rising unemployment in Germany is the result of insufficient reforms and continued deterioration of the supply side.

- Labour and product market reforms such as those recommended by the OECD (and undertaken in the UK) should be implemented with more determination in Germany.

We have argued that there are both theoretical and empirical grounds for pursuing this debate further. On the theoretical side, we showed that the claim that aggregate demand can play an important driving role in explaining persistent weak growth and rising unemployment does not rely on a naïve Keynesian macroeconomic model. Specifically, we used an extended version of the now-standard New Keynesian macro model to show how:

- shifts in aggregate demand in open economies can move the economy along a range of constant-inflation medium term unemployment equilibria.

- In this setting, both 'exogenous' and policy-related shifts in aggregate demand can contribute to the explanation of within-country trends and cross-country differences in unemployment performance.

- The evolution of the real exchange rate and the external balance can help to identify whether aggregate supply or demand shifts have been dominant in accounting for changes in unemployment.

Moreover, on the empirical side, it seems that:

- Germany has a relatively strong record in carrying through OECD-recommended reforms. There has however been little consequent evidence of growth of employment in low-skill service sectors and there has been an increase in poverty especially in younger age groups.

- By contrast, it is in high productivity sectors, including in services that the German economy has performed well, especially in exports; and these are largely sectors in 
which codetermination, vocational education at different levels and coordinated wage bargaining are important.

Taking the cases of the UK and Germany, we have shown that there is some prima facie evidence to suggest that aggregate demand factors have played an important role in sustaining growth in the UK and weakening it in Germany over the medium run. The sharpest contrast is between the strength of the contributions to growth of household and government spending in the UK and its weakness in Germany, especially in the period since 2000. The real appreciation of the sterling exchange rate is consistent with aggregate demand having played a substantial role in the fall in unemployment in the UK after 1997. The strength of German export performance and the industry pattern of employment growth both point toward a predominantly demand rather than supply side explanation of rising German unemployment.

Our analysis points toward two key questions for the reform debate in Germany:

- what does a reform package for Germany look like that will achieve improved macro performance and

- how can political support for such a package be found.

The complementarity between the specificities of the labour market, the training system and the welfare state indicates that only a reform package that takes these features into account is likely to have its intended employment boosting impact without depressing aggregate demand - e.g. via higher savings. It would also appear that there is scope for increasing flexibility in the labour market without adversely affecting consumption and income distribution by removing penalties on second earners in the household and introducing reforms to increase the incentives for women to combine employment with child rearing.

As part of a research agenda to contribute to a reform package, two specific issues emerge from this paper. The first question is how to make it easier for women to move between working at home, especially raising very young children, and market sector employment. Currently, women lose substantially by having children and then returning to work, since they do so at greatly reduced earnings and often conditions. The two well-known consequences are that young women with good career prospects are reluctant to have children; and women who have children and are engaged in home-working are reluctant to return to the market; these consequences are, as is also well-known, compounded by the absence of readily available high quality child-care. Where these problems do not apply as in the Nordic countries, it seems likely that the ability to move relatively costlessly between working at home and in the market acts as an additional mechanism to reinforce the standard insurance provided by the welfare state and thus to reduce the need for building up precautionary savings.

This seems an important area of research in Germany, since it combines the possibility of reducing the savings rate and increasing the reproduction rate. But there are political economy problems: first, attempting to develop guarantees in the private sector is difficult since the interests of male-dominated works councils and sector-based unions are against them (damaging company profitability) - this contrasts with confederal unionization in the Nordic countries. Second, if the public sector was developed as in Scandinavia and Finland, a major (political economy) problem would be to avoid using this as a means to mop up unemployment of low-skilled women with low educational attainment. 
The second item in a research programme would be to examine the claim that flexible labour market reforms designed to promote low income service sector jobs have sharply dysfunctional effects in an environment with insufficient aggregate demand and in the presence in an important part of the economy of a well-functioning labour system based on investment in specific skills. Such effects may include (i) the growth of poverty and limited employment growth in these sectors; (ii) the knock-on effects of poverty on lower end educational and vocational training incentives and attainment.

We believe that it is through a greater understanding of these interactions between macroeconomic questions of insufficient aggregate demand and microeconomic questions of labour markets and training that it may be possible to fashion a programme of reforms tailored to the specificities of the German political economy. 


\section{References}

Adda, J., Dustmann, C., Meghir, C. and J.-M. Robin, (2006). 'Career progression and formal versus on the job training'. Mimeo, UCL.

Aghion, P., and Marinescu, I. (2006). 'Cyclical Budgetary Policy and Economic Growth: What Do We Learn from OECD Panel Data?’ Mimeo Harvard University.

Allard, C., Catalan, M., Everaert, L., and Sgherri, S. (2005). 'Explaining differences in external sector performance among large Euro area countries', IMF Working Paper.

Allsopp, C. and Vines, D. (2005). 'The macroeconomic role of fiscal policy' Oxford Review of Economic Policy, Vol. 21, No. 4.

Baker, D., Glyn, A., Howell, D. and Schmitt, J. (2005). 'Labor market institutions and unemployment: a critical assessment of the cross-country evidence', Chapter 3 of D. R. Howell ed. Fighting Unemployment: The Limits of Free Market Orthodoxy, OUP: Oxford.

Bassanini, A. and Duval, R. (2006). 'Employment patterns in OECD countries: reassessing the role of policies and institutions'. OECD Working Paper 486. (Also summarized in OECD Economic Policy 2006, Chapter 7.)

Blanchard, O. (2005). 'European unemployment: the evolution of facts and ideas', MIT Working Paper 0524.

Brandt, N., Burniaux, J-M and R. Duval (2005). 'Assessing the OECD Jobs strategy: Past developments and reforms'. OECD Working Paper, 429.

Carlin, W. and Soskice, D. (1990), Macroeconomics and the Wage Bargain, Oxford: OUP.

Carlin, W. and Soskice, D. (2005). 'The 3-Equation New Keynesian Model --- A Graphical Exposition', Contributions to Macroeconomics: Vol. 5: No. 1, Article 13. http://www.bepress.com/bejm/contributions/vol5/iss1/art13

Carlin, W. and Soskice, D. (2006). Macroeconomics: Imperfections, Institutions and Policies, OUP: Oxford.

Carlin, W. and Soskice, D. (2007). 'Reformen, macroökonomische Politik under Wirtschaftsentwicklung Deutschland' in R. Schettkat und J. Langkau (Hrsg.) Aufschwung für Deutschland: Plädoyer international renommierterÖkonomen für eine neue Wirtschaftspolitik. Dietz: Bonn.

Card, D. and Freeman, R. (2004). 'What have two decades of British Economic Reform Delivered?' in D. Card, R. Blundell, and R.B. Freeman (2004). Seeking a Premier Economy: The Economic Effects of British Economic Reforms, 1980-2000. University of Chicago Press: Chicago.

Cotis, J.-P. (2006). 'Economic growth and productivity'. Annual Conference, Government Economic Service, Nottingham, July 2006.

Coutinho, L. (2005). 'Fiscal policy in the new open economy macroeconomics and prospects for fiscal policy coordination' Journal of Economic Surveys, 19(5), 789-822.

Dustmann, C., Ludsteck, J. and U. Schönberg (2007). 'Revisiting the German wage structure'. Mimeo, UCL.

Esping-Andersen, G. (1990). The Three Worlds of Welfare Capitalism. Cambridge, UK, Polity Press.

Förster, M. and Miro d'Ercole, M. (2005). 'Income distribution and poverty in OECD countries in the second half of the 1990s' OECD Social, Employment and Migration Working Paper No. 22.

Gali, J., Lopez-Salido, J. and J. Valles (2007). 'Understanding the effects of government spending on consumption' JEEA, 4(5), 227-270. 
Giavazzi, F. and McMahon, M. (2006). 'Waiting for reforms that never come: saving and work in Germany'. Mimeo, LSE.

Glyn, A., Salverda, W., Moeller, J., Schmitt, Sollogoub, M. (2004). 'Employment differences in services: the role of wages, productivity an demand', DEMPATEM Working Paper 12. (forthcoming in W. Salverda, M. Gregory and R. Schettkat ed. Services and Employment: Explaining the US European Gap, Princeton University Press. 2007.

Hall, P. A. and D. Soskice, Eds. (2001). Varieties of Capitalism: the Institutional Foundations of Comparative Advantage, Oxford University Press

Hallerberg, M., Strauch, R. and von Hagen, J. (2001). 'The Use and Effectiveness of Budgetary Rules and Norms in the EU States' Report for the Dutch Finance Ministry.

Heckman, J. (2002). 'Flexibility and job creation: Lessons for Germany', NBER Working Paper 9194.

Heckman, J. and C. Pagés (2003) 'Law and employment: lessons from Latin America and the Caribbean' NBER WP10129, http://www.nber.org/papers/w10129

Hoem, J.M. (2005). 'Why does Sweden have such high fertility?', Demographic Research Vol. 13, Article 22, 559-572, http://www.demographic-research.org/Volumes/Vol13/22/

Höpner, M. (2003). Wer beherrscht die Unternehmen? Shareholder Value, Managerherrschaft und Mitbestimmung in Deutschland. Frankfurt a.M.: Campus.

Howell, D., Baker, D., Glyn, A. and Schmitt, J. (2006). 'Are protective labor market institutions really at the root of unemployment? A critical perspective on the statistical evidence'. Mimeo. New York.

Iversen, T. (2005). Capitalism, Democracy and Welfare. Cambridge, UK, Cambridge University Press.

Krugman, P. (2006). 'Is fiscal policy poised for a comeback?' Oxford Review of Economic Policy, Vol. 21, No. 4.

Layard, R., Nickell, S. and Jackman, R. (1991). Unemployment: Macroeconomic Performance and the Labour Market. OUP: Oxford.

Lijphart, A. (1984). Democracies: Patterns of Majoritarian and Consensus Government in 21 Countries. New Haven, Yale University Press.

McNeil, W. C. (1988). American Money and the Weimar Republic: Economics and Politics on the Eve of the Great Depression. New York: Columbia University Press.

Nickell, S., Nunziata, L., and Ochel, W. (2002). 'Unemployment in the OECD since the 1960s. What do we know?'. Economic Journal. 115 (January), 1-27.

Rowthorn, R. (1977), ‘Conflict, inflation and money’, Cambridge Journal of Economics, 1. 215-39.

Siebert, H. (2005). The German Economy: Beyond the Social Market. Princeton University Press: Princeton.

Soskice, D. (1994). 'Reconciling markets and institutions: the German apprenticeship system' in Lisa M. Lynch (ed). (1994). Training and the private sector Chicago: University of Chicago press, pp. 25-60.

Thelen, K.(2007). "The Future of German Vocational Training, in Light of its Past", Ms. Dept of Political Science, Northwestern University.

Vikat, A. (2004). Women's labor force attachment and childbearing in Finland. Demographic Research Special Collection No. 3 (8), 175-211.

Vogel, S. (2006). Japan Remodeled. Ithaca, Cornell University Press. 
Appendix

\section{Institution variables}
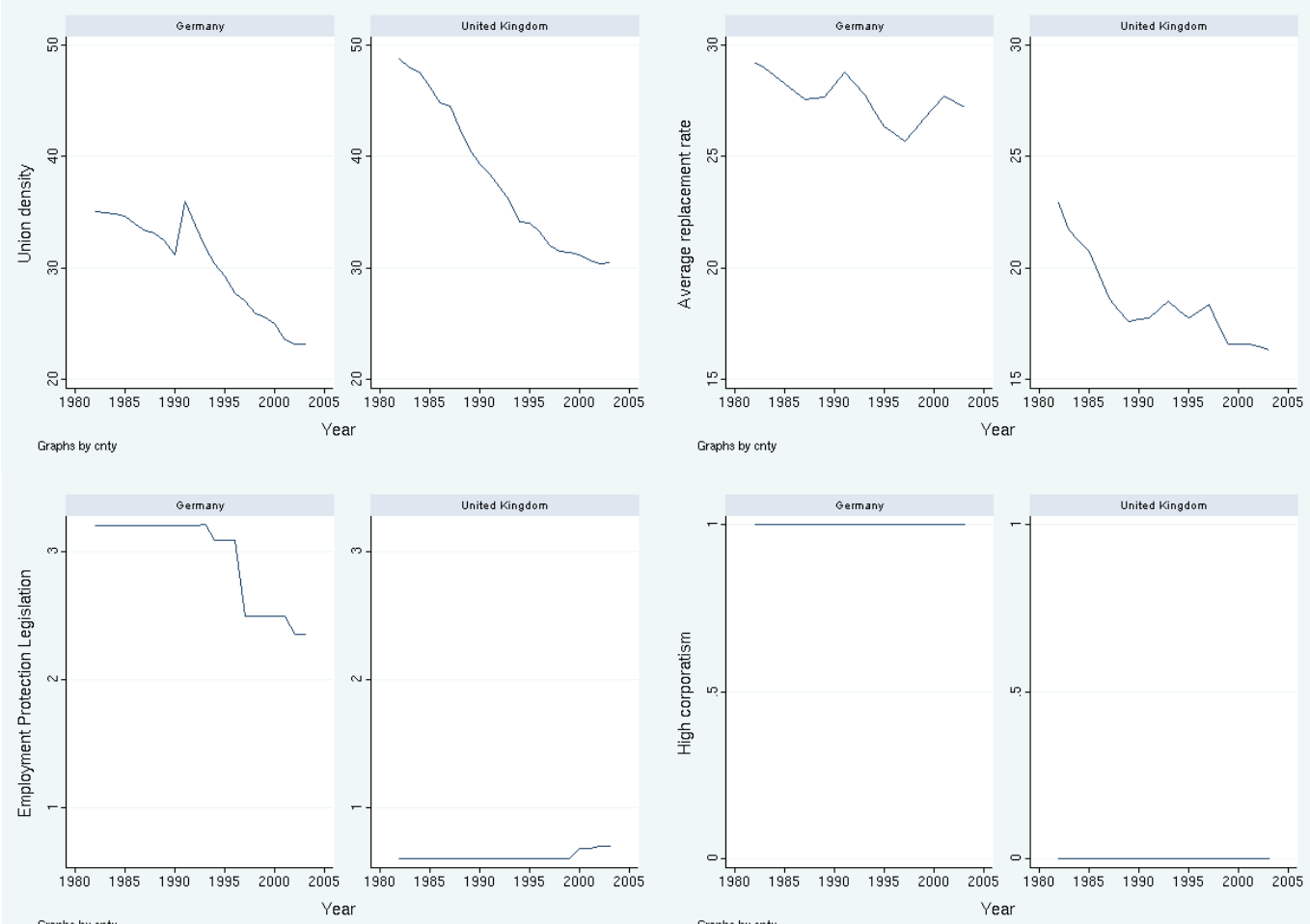

Graphs by crty
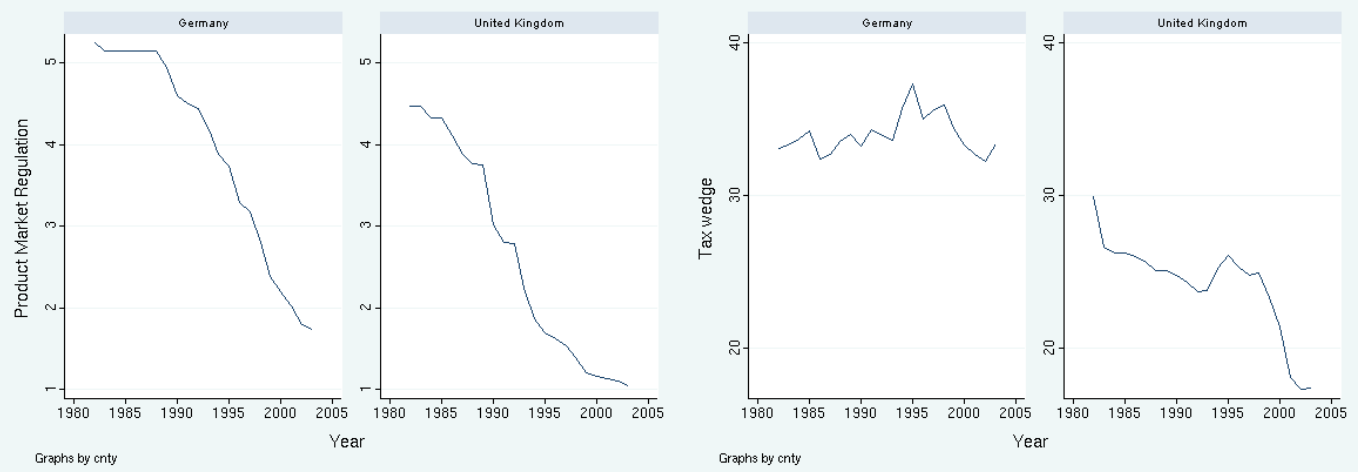

Source: Bassanini Duval database 2006. 


\section{Appendix 2.}

Scoring of labour market reforms introduced in Germany 1994-2004.

Source: Annex 3 of Brandt, Burniaux and Duval (2005).

The following are taken directly from the above source.

EPL:

1994-1999: "Regular contracts" -- company size limit for dismissal protection lifted from 5 to 10 , but this was reversed, score: 0, "Temporary contracts" -- maximum duration and permissible renewal frequency increased with a resulting change in the EPL-indicator of 1.5, score: +3; total score for 1994-1999 equals 3. 2000-2004: "Regular contracts" -- size limit for dismissal protection lifted from 5 to 10, this reform is not reflected in the EPL indicator, score: +1 "Temporary contracts" -- maximum age for restrictions on the renewability of fixed-term contracts decreased and the maximum duration for contracts through temporary work agencies eased further with a corresponding decrease of the EPL-indicator of 0.2 , score: +1 ; total score for 2000-2004 equals 2.

Overall score for the 1994-2004 period equals 2.5; the overall score expressed as a percentage of the maximum score $(=15$, that is a total of 6 for a change in the EPL indicator bigger than 0.6 for both temporary and regular contracts plus 9 extra points) takes a value of 16.67 per cent.

Unemployment benefits:

1994-1999: work availability requirements were tightened, score: +1 ; eligibility conditions tightened, score: +1 ; concerning the benefit replacement rate, crediting of redundancy payments against unemployment benefits was introduced and reversed in 1999, score: 0 .

2000-2004: wage base for benefit calculation extended resulting in an average increase of the replacement rate of 1.8 per cent, but in 2004 , it was decided to reduce benefits sharply beginning in 2005 , to capture the latter reform measure a score of +1 is assigned; benefit duration lowered: +1 ; work availability criteria tightened: +1 .

Overall score for the 1994-2004 period: 2.5, as a percentage of the maximum score (=13): 19.2 per cent.

Work time flexibility:

1994-1999: 1 point in the category "Flexibility of working time arrangements" for the introduction of working time accounts.

2000-2004: employees obtain a right to unilaterally transform a full-time job into a part-time job, score: 0 because it is not clear that the possibility to transform full-time into part-time jobs without the employer's consent eases constraints in a way that more job creation is to be expected.

Overall score for the 1994-2004 period: 0.5; as a percentage of the overall score (=3): 16.7 per cent.

Early retirement:

1994-1999: entry ages to different retirement schemes gradually increased, involving a drop in the average implicit tax of 1.7 percentage points, score: 1; introduction and subsequent suppression of reforms to the sick pay and the disability pension system, score: 0 .

2000-2004: early retirement involves discounts and unemployment benefit pathway to early retirement is phased out progressively as the exemption of older workers from job search requirements expire, involving an average reduction in the implicit tax of 11.5 percentage point, score: +2 .

Overall score for the 1994-2004 period: 1.5; as a percentage of the overall score (=6): 25 per cent.

Wage formation:

1994-1999: 1 point in "Wage determination" for an increase in plant-level agreements over the 1990s; 1 point in "Use of opt-out clauses".

2000-2004: no action, score: 0 .

Overall score for the 1994-2004 period: 1; as a percentage of the maximum $(=13)$ : 9.1 per cent.

Active Labour Market Policies:

1994-1999: evaluation efforts stepped up, score: +1; ALMPs were targeted more on the long term unemployed, the young and older workers, with some of these programmes being new, consequently 1 point was assigned in the category "Targeting of ALMPs" together with a point in the category "Extent of ALMPs"; ALMPs were re-oriented towards encouraging job search while inefficient job creation programmes were scaled down, for this measure a point was assigned in the category "Integration and 
restructuring of ALMP activities" and a point in the category "Extent of ALMPs" for enhancing the job search function of the PES (resulting in a total of 2 points in this category); one point was assigned in the category "Re-qualification via ALMPs" for abolishing re-qualification via training programmes.

2000-2004: evaluation efforts stepped up once more, score: +1 ; for profiling, corresponding to an enhancement of the job search function of the PES, for individual action plans to become mandatory in 2005 and for efforts to introduce early activation, a score of 4 is assigned in the category "Extent of ALMPs"; a supplementary point in "Targeting of ALMPs" is assigned for early activation of young jobseekers; in "Contestability of PES" 1 point for introducing the possibility to outsource placement to private agencies is assigned; in "Integration of job counselling, ALMPs and various benefit agencies", 2 points are assigned for the centralisation of the responsibility for the long-term unemployment in one agency that will be introduced in 2005; a further point is assigned in the category "Re-qualification via ALMPs" for abolishing the possibility to re-qualify.

Overall score for the 1994-2004 period: 7.5; as a percentage of the maximum score (= 13): 57.7 per cent.

Taxes on labour income:

1994-1999: "Overall taxes on labour income" -- labour tax decreases along with some increases and some decreases in social charges with a resulting increase in the tax wedge by 0.8 per cent, score: -1 ; "Taxes for low income" -- increases in tax allowances and in the lowest tax rate, social charges for "Minijobs" introduced with a resulting decrease of the average of the three tax wedges of 1.1 per cent, score: +1 .

2000-2004: "Reduction on taxes in labour income": tax rate decreases across all income ranges with a resulting decrease in the tax wedge of 0.8 per cent, score: +1 ; increase of the earnings ceiling for "Minijobs" and rebates of social charges for income ranges just above that ceiling with a resulting decrease in the average of the three tax wedges for low income of 0.8 per cent, score: +1 .

Overall score for the 1994-2004 period: 1, the overall score expressed as a percentage of the maximum score $(=8): 12.5$ per cent which is the reform intensity indicator. 